\title{
Do Credit Shocks Matter? A Global Perspective*
}

\author{
Thomas Helbling ${ }^{\mathrm{Y}}$ \\ Raju Huidrom ${ }^{\mu}$ \\ M. Ayhan Kose ${ }^{\mathrm{Y}}$ \\ Christopher Otrok ${ }^{\mu \beta}$
}

July 2010

\begin{abstract}
This paper examines the importance of credit market shocks in driving global business cycles over the period 1988:1-2009:4. We estimate common components of various macroeconomic and financial variables of the G-7 countries. We then undertake a variety of exercises to evaluate the role played by credit market shocks using a global VAR model. Our findings suggest that these shocks do matter in explaining global business cycles. In particular, they have been influential in driving global activity during the 2009 global recession. We also study the global implications of credit market shocks originating in the U.S. We show that the U.S. credit market shocks have a significant impact on the evolution of global growth during the latest episode.
\end{abstract}

Copyright Rests With Authors

* We would like to thank David Fritz and Ezgi Ozturk for providing outstanding research assistance. The views expressed in this paper are those of the authors and do not necessarily represent those of the IMF or IMF policy.

${ }^{\beta}$ Corresponding author

Y International Monetary Fund, Research Department; thelbling@imf.org (Helbling); akose@imf.org (Kose).

${ }^{\mu}$ University of Virginia, Department of Economics; rh2cw@virginia.edu (Huidrom); otrok@virginia.edu (Otrok) 


\section{Introduction}

The global financial crisis of 2007-09 that originated in U.S. credit markets rapidly spread across borders and led to recessions or severe downturns in almost all advanced economies and many emerging economies at the same time. The global reach and depth of the crisis, which are without precedent in the post-World War II period, have renewed interest in the linkages between the real economy and credit markets and have triggered an intensive debate about the importance of shocks originating in financial markets for business cycles. Our objective in this paper is to attempt to answer one of the central questions of this debate: Do credit shocks matter in the global economy?

We study this question by analyzing the importance of a fairly comprehensive set of shocks in the context of G-7 countries. We estimate common components of various macroeconomic and financial variables, and examine the roles played by credit shocks in explaining global business cycles employing a set of VAR models. In addition, we study the transmission of credit shocks in the U.S. to the global economy using a factoraugmented VAR (FAVAR). Our results suggest that credit shocks play an important role in the global recessions.

Our study contributes to a large body of research focusing on the interactions between financial markets and the real economy. A short review of this literature reveals the central nature of the question we are studying. Depending on the class of models under consideration, the role of credit markets in driving business cycles varies substantially. While some models consider that the credit markets are only peripherally important for the dynamics of business cycles, some others assign a significant importance to the shocks originating in credit markets. ${ }^{1}$

\footnotetext{
${ }^{1}$ While the early literature did recognize that financial markets play an important role in the real economy, this emphasis later faded. Shocked by the experiences of the Great Depression, Fisher (1933) and Keynes were among the first to emphasize the importance of financial markets in shaping macroeconomic outcomes. Subsequent research, however, focused largely on the role of money as the most relevant financial variable to aggregate economic behaviors. The famous Modigliani and Miller (MM) (1958) "capital structure
} 
Basic economic theory suggests that, in a frictionless world under complete markets, macroeconomic and financial variables can interact closely through wealth and substitution effects. Developments in credit markets, which are simply reflected by movements in asset prices, can influence consumption through their impact on household wealth, and can affect investment by altering a firm's net worth and the market value of the capital stock relative to its replacement value (see Campbell, 2003; Cochrane, 2006). However, in models with complete markets, the financial sector is a "veil" in the sense that there is no role for financial intermediaries or credit market disturbances, since these models do not consider financial imperfections/frictions. These models, hence, imply that shocks originating in credit markets play only a minor role, if any, in explaining business cycles.

In theory, interactions between financial variables and the real economy can be amplified when financial imperfections are present. ${ }^{2}$ This amplification largely occurs through the financial accelerator and related mechanisms operating through firms, households and countries' balance sheets. According to these mechanisms, an increase (decrease) in asset prices improves an entity's net worth, enhancing (reducing) its capacities to borrow, invest and spend. This process, in turn, can lead to further increases (decreases) in asset prices and have general equilibrium effects (e.g., Bernanke and Gertler, 1989; Bernanke, Gertler, and Gilchrist, 1999; Kiyotaki and Moore, 1997; and numerous other studies on the role of financial imperfections). In other words, disturbances in credit markets can translate into much larger cyclical fluctuations in the real sector in these models. ${ }^{3}$

irrelevance" hypothesis and the general focus on efficient financial markets, however, may have inadvertently drawn attention away from the relevance of financial structure for macroeconomic performance.

${ }^{2}$ Surveys of this literature can be found in Gertler (1988), Bernanke (1993), Lowe and Rohling (1993), and Bernanke, Gertler, and Gilchrist (1996), and Gilchrist and Zakrajsek (2010).

${ }^{3}$ Some recent studies have focused on the role of asset prices as vehicles in transmitting financial cycles (Adrian and Shin, 2009; and Geanakoplos, 2009). Recent studies also consider how the state of the financial system can affect business cycles (Gertler and Kyotaki, 2010; Brunnermeier and Sannikov, 2010). 
Other studies applying models of frictions in credit markets to open economies have considered how the dynamics of another asset price, exchange rate, relate to business cycles (see Cespedes, Chang and Velasco, 2004). ${ }^{4}$ This line of research also studies how fluctuations in asset prices can affect the value of collateral required for international funding (see Mendoza, 2010). Caballero and Krishnamurthy (1998) and Schneider and Tornell (2004) model how, because of balance sheet constraints, fluctuations in credit and asset markets translate into boom-bust cycles in emerging market economies. ${ }^{5}$

Many empirical studies provide evidence regarding the linkages between the dynamics of business cycles and disturbances in credit markets (e.g., Bernanke and Gertler, 1989; Borio, Furfine and Lowe, 2001). Many of these examine the procyclical nature of credit cycles and business fluctuations, albeit mostly for single country cases. For example, Bordo and Haubrich (2010) analyze cycles in money, credit and output between 1875 and 2007 in the United States. They show that financial stress events exacerbate cyclical downturns. While most studies have used aggregate data, some credit-related studies have been based on micro data (banks or corporations). ${ }^{6}$

Our paper is closely related to some recent studies analyzing the importance of credit shocks using VAR models. Meeks (2009) examines the importance of credit shocks in explaining U.S. business cycles. He documents that credit shocks do play an important role during financial crises, but they have a lesser role during normal business cycles. Gilchrist, Yankov and Zakrajsek (2009) and Gilchrist and Zakrajek (2010) report that credit market spreads have a significant impact on business cycles in the U.S. during the period 1990-2008.

\footnotetext{
${ }^{4}$ Earlier work includes Krugman (1999) and Aghion, Bacchetta and Banerjee (2000).

${ }^{5}$ There is also a rich set of theoretical studies analyzing the implications of various types of financial crises for the real economy (see Gorton, 2009 as regard to the recent financial crisis).

${ }^{6}$ See Bernanke, Gertler and Gilchrist, 1996; Kashyap and Stein, 2000; and Kannan, 2010.
} 
Our paper attempts to address some of the major gaps in this literature. First, our study is the first one to analyze the global dimensions of credit shocks. Second, in addition to well-known credit spread measures, we examine the importance of fluctuations in the volume of credit. Third, we go beyond the basic analysis of impulse responses and variance decompositions and study the role played by credit shocks during certain episodes. This is particularly important given that the latest financial crisis is associated with severe disruptions in credit markets showing the potentially important role of disturbances in these markets can play in driving business cycles.

In section II, we introduce our database and explain the econometric approach. The database comprises quarterly series of credit, credit spread, GDP, labor productivity, inflation, and the interest rates of the G-7 countries over the period 1988:1-2009:4. The main variable we use to characterize business cycles is output (GDP) since it is the best (available) measure to evaluate economic activity. We study credit market developments considering fluctuations in both credit volume and credit spreads. In order to study the global dimensions of credit shocks, we construct a global equivalent of each variable in our database. This involves estimation of global factors. We employ a set of VAR models to analyze the importance of various shocks in explaining business cycles. In particular, we focus on four types of shocks: credit, policy, productivity, and demand shocks. Our approach to identification of shocks is an agnostic one as we use intuitively appealing sign restrictions.

In section III, we construct a global VAR composed of the global factors in credit, GDP, inflation, interest rates, labor productivity, and U.S. credit spreads. We then analyze how global credit shocks affect global business cycles using impulse responses and variance decompositions. We also study how these shocks affect the evolution of global GDP during global recessions. To undertake this exercise, we conduct a number of counterfactual simulations.

In Section IV, we focus on the role of credit market shocks originating in the U.S. using a FAVAR model. The model includes U.S. variables along with the global GDP factor. We 
study how the credit shocks affect U.S. macroeconomic aggregates. In addition, we analyze how these shocks are transmitted to the global economy considering their impact on global GDP. We conclude in Section V with a brief summary of our main results and directions for future research.

\section{Database and Methodology}

\section{II.1. Database}

Our dataset includes quarterly series of credit, credit spread, GDP, labor productivity, inflation, and the interest rates of the G-7 countries during the period 1988:1-2009:4. We are interested in this period because of the following reasons. First, it is a common denominator for the cross-country data we need to analyze the interaction between credit shocks and business cycle dynamics in the G-7 countries. Second, this period covers a substantial portion of the era of the so-called "Great Moderation" as well as the latest global financial crisis. ${ }^{7}$ Third, this period also coincides with a rapid increase in trade and financial linkages across these countries and overlaps with a broader converge of their business cycles (see Kose, Otrok, and Whiteman, 2008). ${ }^{8}$

Our measure of credit is aggregate claims on the private sector by deposit money banks. This measure is also used in earlier cross-country studies on credit dynamics (see Mendoza and Terrones, 2008 and Claessens, Kose, and Terrones, 2009 and 2010). The use of credit volume differentiates our study from most others analyzing the impact of credit shocks and allows us to construct a global credit factor since this variable is

\footnotetext{
${ }^{7}$ The era of Great Moderation started in the mid-1980s and coincided with a structural decline in the volatility of business cycles in industrial countries until the financial crisis of 2008-09. For details about the Great Moderation, see Blanchard and Simon (2001), McConnell and Perez-Quiros (2000) and Stock and Watson (2005).

${ }^{8}$ In particular, using a dynamic factor model, Kose, Otrok and Whiteman (2008) find that that the degree of comovement of business cycles in major macroeconomic aggregates across the G-7 countries has increased during the globalization period starting in the mid1980s.
} 
available for all of the G-7 countries at the quarterly frequency. ${ }^{9}$ We deflate the nominal credit series using the CPI to produce real credit. Inflation corresponds to the changes in each country's CPI. Both credit and CPI series are from the International Financial Statistics (IFS).

In order to measure credit spreads, we use corporate bond spreads. Although all of the other variables we use are available for all the G-7 countries, credit spread series are available for only the U.S. In particular, these spreads are the yield differences between Moody's Seasoned Aaa and Baa corporate bonds for the U.S. The Aaa bonds are "judged to be the highest quality with minimal credit" risk while the Baa bonds are "subject to moderate credit risk and possess certain speculative characteristics”. Since the original spread data is monthly, we take the observation of the last month of each quarter as our quarterly spread. We obtain the bond spreads data from the Board of Governors of the Federal Reserve System.

There is no single accepted measure of credit spreads as the recent literature on the importance of credit shocks employs various alternative ones. For instance, Meeks (2009) uses a measure of credit spreads defined in terms of a risky portfolio that belongs to Moody’s B1/B2 category. Such a portfolio is described by Moody's as being subject to "high credit risk". Gilchrist, Yankov and Zakrajsek (2009) take a panel of credit spreads and use the common factor of these spreads as their credit spread measure.

We track aggregate business cycles with GDP since it is the single best available measure to monitor economic activity. Our GDP data are chained volume series from the OECD. The interest rates correspond to nominal short term government bill rates, generally Treasury Bill Rates, and are from the IFS. Labor productivity is the labor productivity of

\footnotetext{
${ }^{9}$ Only a few others include credit volume to study the impacts of credit market shocks on the real economy. One exception is Balke (2000) who uses a different measure of credit volume, which is bank loans and commercial paper in total firm external finance.
} 
the total economy defined as real GDP per hours worked and is obtained from the OECD. We provide a detailed list of data series and their sources in Appendix A.

Before constructing our factors and estimating the VAR models, we make appropriate transformations in each data series. In particular, we take four-quarter growth rates of GDP, labor productivity, and credit. Interest rates are first differenced and credit spreads are in levels. All variables are seasonally adjusted and in percentages.

\section{II.2. Methodology}

Since our objective is to analyze the global dimensions of credit shocks, we undertake our exercise in two steps. First, we construct a global equivalent of each variable. This step simply involves estimation of global factors. Our data sample includes only G-7 countries, but this country group accounts for slightly more than half of global GDP over the 1998-2009 period (in PPP exchange rates). Second, we employ VAR models to analyze the importance of various shocks in explaining business cycles. We also consider how the shocks originating in the U.S. transmit to the global economy using FAVAR (Factor Augmented VAR) models. We now briefly explain each step in turn.

\section{Estimation of Global Factors}

In order to estimate the global factors, we extract the first principal component of each variable using the series of the G-7 countries. There are of course various approaches to construct global equivalents of variables we have. For example, an alternative would be to do an exact dynamic factor analysis like the one in Kose, Otrok, and Whiteman (2003). Their method is especially useful when studying global, regional, and country specific factors and their importance in explaining national business cycles. However, the global factor estimated using the dynamic factor models is quite similar to the first principal 
component we extract here. ${ }^{10}$ For convenience, we use the simpler approach here, since we are only interested in the global component of each variable.

Figure 1 presents the estimated global factors. The estimated factors are broadly consistent with a number of well-known cyclical episodes in the global economy. For instance, the downturns in the estimated global GDP factor coincide with the recessions of the early 1990s, early 2000s, and the latest episode of 2007-2009. The downturn during the latest episode is particularly striking because of its highly synchronous nature and its unprecedented depth. The estimated factors of the other variables also reveal some interesting patterns. For example, the global credit factor indicates that all three recessions we discuss above are associated with a decline in credit. The global inflation factor shows a steady decline in inflation beginning in the early 1990 until the recent episode consistent with the widely documented observation in the literature about the "conquest of inflation" in advanced economies. The global interest rate factor is also consistent with the well known episodes: the rapid increase in the late 1980s and early 1990s, and then the decline during the recent period due to the coordinated easing of monetary policy among the advanced economies. Figure 1 also presents the evolution of the U.S. credit spread. Although there are small elevations in spread series during the early 1990s and 2000s, the latest episode is truly in a different league as the spread climbs to 3 percent which is more than double of its previous highest value over the 1988-2007 period.

We are able to estimate global factors for all variables except the credit spread, since we have the spread series for only the U.S. We assume that credit spread for the US is a good proxy for the global credit spread since the U.S. economy is dominant in both global real and financial markets. Over the period of 1988-2009, the U.S. economy constitutes roughly half of the G-7 output while it accounts for almost one-fourth of global output. Moreover, the U.S. financial markets are the largest, reflecting not only the size of the

${ }^{10}$ In fact, we did estimate the dynamic factor models for some of the variables and arrived at almost identical factors to those from the principal component models. 
economy but also their depth. For example, capitalization of the U.S. equity markets accounts for around 40 percent of total capitalization of world equity markets. Changes in U.S. credit markets and asset prices have strong signaling effects worldwide, and spillovers from U.S. financial markets have been important, especially during periods of market stress.

\section{VAR Models}

We estimate two VAR models. The first one is a "global" VAR model including the estimated global factor of each variable and the U.S. credit spread. The second model is a FAVAR as it uses the U.S. specific variables along with the global GDP factor. ${ }^{11}$ The models we have can be represented by:

$$
Y_{t}=A_{(0)}+A_{(1)} Y_{(t-1)}+A_{(2)} Y_{t-2}+\ldots .+A_{(1)} Y_{t-1}+u_{t} ; t=1, \ldots, T
$$

where $Y_{t}$ is an $m \times 1$ vector of variables at date $t, A_{i}$ is an $m \times m$ coefficient matrix for each lag of the variable vector with $A_{(0)}$ being the constant term. $u_{t}$ is the vector of onestep ahead prediction error. The global VAR and the U.S. FAVAR differ only in terms of the set of variables in the $Y_{t}$ vector. For the global VAR, $Y_{t}$ includes the estimated global factors and U.S. credit (i.e., corporate bond) spread. ${ }^{12}$ In the case of the U.S. FAVAR, the vector consists of the set of U.S. variables and the global GDP factor. In our estimation, the lag length, $l$, is kept at four.

We use these models to examine the roles of four shocks in explaining the global and U.S. business cycles: credit, policy, productivity, and demand shocks. In addition to

\footnotetext{
${ }^{11}$ Our model follows the work of Bernanke, Bovin, and Eliasz (2005) who developed the factor-augmented VAR (FAVAR) to study the effects of monetary policy in a closed economy framework.

12 Bernanke, Bovin, and Eliasz (2005) compare FAVARs that treat estimated factors as data as is done here, with more sophisticated Bayesian estimates that account for uncertainty in the estimated factors. They find that there is no real gain from the more computationally intensive Bayesian methods for this type of problem.
} 
credit market shocks, we focus on the shocks stemming from changes in policies, productivity, and demand since different classes of models emphasize their importance in explaining business cycles. We use global and the U.S. specific versions of these shocks in our respective models of the global economy and the U.S.

We identify the shocks using the idea of sign restrictions imposed on impulse responses following Uhlig (2005). ${ }^{13}$ Instead of relying on informational orderings about the importance of shocks, this identification approach allows us to produce impulse responses that are qualitatively consistent with the standard theoretical predictions. The sign restrictions we impose are indeed intuitively appealing. For example, we identify adverse credit market shocks as those that correspond to a decrease in credit and an increase in credit spreads for four quarters following the initial shock. While this identification scheme describes the natural responses of volume and price of credit to disturbances in credit markets, it does not impose any restriction on the response of GDP.

Analogously, our contractionary policy shocks are identified by assuming that they are associated with an increase in the interest rates, a fall in GDP, a fall in inflation, and a fall in credit spreads. The fall in credit spreads, the last restriction we impose to identify policy shocks, purges these shocks from credit shocks. To identify positive demand shocks, we consider these shocks coinciding with an increase in both GDP and inflation. Lastly, the identification of a positive productivity shock implies that such a shock corresponds to an increase in labor productivity, an increase in GDP, and a fall in inflation. The latter restriction on inflation can be formally derived from a New Keynesian DSGE model. In that model inflation is driven by marginal cost, and positive productivity shocks lower marginal cost.

\footnotetext{
${ }^{13}$ Uhlig (2005) employs this method in a different context as he considers the importance of monetary policy shocks by imposing sign restrictions on the impulse responses of prices, nonborrowed reserves and the federal funds rate in response to a monetary policy shock.
} 
We keep the horizon for sign restrictions for all of the shocks at four quarters to maintain symmetry across different shocks. The horizon of four quarters also captures the idea that each shock persists for at least a year. ${ }^{14}$ We conduct sensitivity exercises to check the robustness of our results to alternative identification restrictions and their durations and all of our main results are robust to these variations.

\section{Credit Shocks and Global Business Cycles}

In this section, we place the global factors in credit, GDP, inflation, interest rates, and labor productivity in our global VAR model, together with U.S. credit spreads. With this model, we estimate the autoregressive dynamics among the variables we are interested in, and identify global credit shocks as well as other shocks we listed in the previous section. We estimate the global VARs over our sample period of 1988:1-2009:4. We analyze the role of worldwide credit shocks in explaining global business cycles in three steps. First, we consider the impulse responses of the variables in our global VARs to these shocks. Next, we study the variance of global GDP attributed to credit and other shocks. Third, we conduct a series of counterfactual simulations to evaluate the role of credit shocks during global recessions.

\section{III.1. Impulse Responses of Global VARs}

Figure 2 shows the median impulse response functions to an adverse global credit shock, together with the 14 and 86 percentile responses (based on 5000 draws). The shapes of these impulse response functions are broadly consistent with our expectations. A temporary adverse credit shock, by assumption, raises corporate bond spreads and reduces total credit at impact. The limited availability and higher price of credit in turn dampen global activity and put downward pressure on prices. The global GDP factor

${ }^{14}$ The selection of horizon length closely follows Peersman and Straub (2009) who also use the same horizon restriction to identify technological shocks for the Euro area. There are other studies that keep the sign restriction horizon shorter than the one we use. For instance, Uhlig (2005) identifies monetary shocks by keeping the sign restrictions horizon at 2 quarters. In the specific context of credit market shocks for the U.S., Meeks (2009) identifies this shock by imposing sign restrictions on spreads for 2 quarters and those on defaults for 12 quarters. 
declines at impact, as does the global inflation. Short-term interest rates fall as well, presumably reflecting monetary easing in response to an unexpected tightening in credit markets. This is reassuring because it suggests that with our identification assumption, we do not capture monetary policy-induced credit tightening. The dampening effects of a credit shock gradually intensify over 2 quarters for real-sector variables (GDP and labor productivity) and over 4 quarters for nominal variables (inflation and interest rates) before they fade gradually.

The direct impact of credit shocks on the key variables capturing the credit channel, the global credit factor and the spreads, which serve to identify the credit shocks, are statistically significant. Beyond the direct credit market effects, the transmission of these shocks to other variables also conforms to conventional wisdom, but the dynamic effects are not always statistically significant. Importantly, however, the output effects are significant. ${ }^{15}$

We present the responses to other global shocks in Figures B1-B3 in Appendix B. As in the case of credit shocks, the impulses due to policy, productivity, and demand shocks generally have the expected patterns in terms of signs. However, they are not statistically significant except for the initial four quarters imposed for identification. In particular, our results suggest the responses of credit variables to other shocks are not always significant and often surprisingly muted. This aspect of our findings highlights that the transmission of shocks through credit channels may not always be relevant.

We also analyze the robustness of our results with respect to different identification schemes. Specifically, we identify credit shocks by selecting only impulse responses with either a positive credit spread response or a negative credit growth response. The results are virtually identical to those obtained with our baseline identification scheme. ${ }^{16}$

${ }^{15}$ The significance of impulse responses of spreads and credit is valid only during the initial 4 quarters where we restrict them a priori to identify credit shocks.

${ }^{16}$ These results are available from the authors upon request. 


\section{III.2. Variance Decompositions of Global VARs}

The insignificance of the responses of global real and nominal variables to credit shocks does not necessarily imply that these shocks are not important. In fact, our variance decompositions suggest that measured by their contribution to fluctuations to the global GDP factor, credit shocks are as important as other shocks. We report our findings in Table 1. The reported variance decompositions are not based on a set of orthogonal shocks that add up to 100 percent. Instead, they reflect a sequence of variance decompositions, each one for one structural shock at a time (with the shocks identified as discussed above). In other words, each cell refers to the contribution of the respective shock to the variance of a particular variable while the rest of the variance is accounted by all other potential unidentified shocks.

The credit shock, for example, accounts for roughly 14 percent of the 12-quarter ahead forecast error variance of the global GDP factor, implying that a universe of other, orthogonal but unidentified, shocks account for the rest. Consequently, the fact that our plain vanilla demand shock accounts for 10 percent as well does not imply that the contributions of credit and demand shocks together add up to 25 percent, as they would in a standard decomposition. Instead, our decompositions suggest that credit shocks account for about as large a share of fluctuations on their own as other, standard structural macroeconomic shocks. Productivity and policy shocks account for approximately 13 and 12 percent of variation in global GDP, respectively.

In addition to global GDP, credit shocks play an important role in explaining the variance of other variables. For example, these shocks explain almost 13 percent of the variance of global productivity. They account for around 15-16 percent of variation in inflation and interest rates. We have so far focused on the importance of credit shocks over the period 1988-2009. We now turn to a different exercise and consider how these shocks affect global GDP during certain episodes.

\section{III.3. Credit Shocks during Global Recessions}


How important are global credit shocks during episodes of global recessions? This is an obvious question to ask given that the latest episode is a global event associated with serious problems in global credit markets. We also consider the roles played by credit shocks during the global recession of 1990-1991. These two episodes of global recessions correspond to declines in world real GDP per capita. ${ }^{17}$ While the Great Recession of 2007-2009 is associated mainly with financial sector problems, the previous global recession reflects a host of issues in various corners of the world: difficulties in the U.S. saving and loan industry, banking crises in several Scandinavian economies, adverse effects of an exchange rate crisis on a large number of European countries, challenges faced by the east European transition economies, and the uncertainty stemming from the Gulf War.

To gauge the role of credit shocks during these episodes, we perform a number of counterfactual exercises. Each of these counterfactual exercises represents simulations where the structural shock of interest is set to zero over the relevant period. In the case of the latest episode, for example, the counterfactual credit shock simulation shows how the global GDP factor would have evolved without the adverse "credit event" that has been the hallmark of the Great Recession. It is important to recognize that this exercise sets the shock itself to zero, but that does not imply that, say, the volume of credit does not contract. Other shocks may also affect credit, and credit may respond endogenously to other variables such as output through the lag structure of the VAR. What we are eliminating then, is the unforecastable shock that drove up credit spreads and lower credit volume.

The top panel in Figure 3 compares the results of counterfactual simulations for the global GDP factor during the Great Recession episode. Specifically, it shows the differences between the actual cumulative change in the demeaned global GDP factor and

${ }^{17}$ Our definition of global recessions follows Kose, Loungani, and Terrones (2010). In particular, they identify four troughs in global economic activity over the past 50 years1975, 1982, 1991, and 2009. 
the cumulative changes in the simulated values in the absence of the global credit shock over the 2007:3-2009:4 period. It is obvious that the impact of the global credit shock has become more pronounced as the recession has translated into a global event spreading from the U.S. to other advanced countries. For example, without the credit shock, the global recession would have been about 25 percent milder based on the differences between the actual and simulated cumulative growth numbers in 2009:3.

Figure 4 presents the contribution of each shock to the cumulative global GDP growth based on counterfactual exercises. Comparing the counterfactual simulations across shocks suggests that credit shocks on their own account for a larger share of the cumulative change in the global GDP factor than the other shocks. We interpret this result as evidence for the important role of credit shocks in the Great Recession.

Counterfactual simulations for the 1990-1991 global recession suggests, however, that credit shocks have not always played the important role as they have done in the most recent downturn. This can be seen in the middle panel of Figures 3 and 4, which show the results from counterfactual simulations for that episode. These results suggest that while credit shocks appear to have played some role in the 1991 downturn, their role is less stark than it is in the 2008-2009 downturn. This finding is an intuitively appealing one. As we discuss above, unlike the 2007-2009 episode which is mainly driven by difficulties in credit markets, the 1990-1991 global recession stems from a variety of problems. As we show in the next section, the impact of credit shocks is quite sizeable during the 19901991 episode in the U.S. where credit markets went through a prolonged period of contraction. Moreover, the latest episode is a truly synchronized one as both real and financial sectors of the G-7 countries simultaneously experience major disruptions. ${ }^{18}$

\footnotetext{
${ }^{18}$ Imbs (2010), using monthly data on industrial production, concludes that the degree of cross-country business cycle correlations during the latest crisis was the highest in three decades.
} 
In addition to the global recessions of 1991 and 2009, we consider the downturn in global growth in 2001 where a number of advanced countries experience much milder recessions. ${ }^{19}$ This episode is associated with the bursting of "dot-com" equity bubbles in a number of advanced countries following the rapid acceleration of stock prices of IT companies during 1995-2000. We present the results for the 2001 episode in the bottom panels of Figures 3 and 4. Given the equity market related nature of the 2001 episode along with its milder effect on global GDP, credit shocks appear to have played a somewhat stabilizing, albeit minimal, role. Hence, the decline in the global credit factor would have been an endogenous response to the downturn in activity (and problems in other segments of the financial sector, especially equity markets).

The conclusions we draw from the analysis in this section is that credit shocks matter for the global economy, albeit to varying degrees. Their effects may not generally be large, but credit shocks have played an important role in some episodes, notably during the latest global recession. Such ambiguities in the effects of credit shocks are not new. Other studies analyzing the relationship between financial conditions and future economic activity and inflation at the country level have also often found weak and unstable predictive power. ${ }^{20}$ One notable exception is that of Gilchrist, Yankov and Zakrajsek (2009) who argue that the predictive power of credit spreads for economic activity

${ }^{19}$ According to Kose, Loungani, and Terrones (2010), the year 2001 does not get identified as a global recession since world real GDP per capita did not decline. Although many advanced countries had recessions, growth in major emerging markets such as China and India remained robust during that period.

${ }^{20}$ There is a large literature analyzing the predictive power of financial variables for future activity. However, the predictive value of these financial variables, including asset prices, generally is limited. Indeed, in their review, Stock and Watson (2003) conclude: "Some asset prices have been useful predictors of inflation and/or output growth in some countries in some periods." In addition, the leading indicator property of asset price changes appears to be limited to certain classes of assets and dependent on the depth of asset markets in the different countries. A number of studies have documented the predictive value of interest rates for output fluctuations and the timing of recessions and recoveries. Specifically, the slope of the yield curve or the term spread-the difference between the long and the short-term interest rate-has long been recognized to have significant predictive power (see Wheelock and Wohar, 2009 for a recent review). 
increases substantially, especially at longer horizons, when the measure of credit spreads is derived from securities issued by intermediate-risk rather than high-risk firms.

\section{The Global Transmission of U.S. Credit Shocks}

We have so far considered the role played by global credit shocks in explaining global GDP. There is much to be said about rapidly increasing international financial linkages, which have led to the speedy transmission of domestic credit shocks to other economies. National and global credit shocks may thus have partly become indistinguishable. Nevertheless, in view of the key role of the U.S. financial system in global financial markets and the large size of the U.S. economy, a key question is whether credit shocks that originate in the U.S. have international repercussions. In this section, we examine this question by analyzing a set of FAVAR models with U.S. variables along with the global GDP factor estimated earlier. As in the previous section, we consider the role of U.S. credit shocks by first studying impulse responses, then variance decompositions, and finally global recession episodes.

The impulse response functions to a U.S. credit shock are shown in Figure 5. The shapes of the median responses are broadly similar to those of the global VAR in the previous section, but there also are some differences. In particular, the impact effects of a 1 standard deviation credit shock on most of the variables are more modest than those in the case of the global VAR. A major feature of the effects of a U.S. credit shock is that it has noticeable international repercussions. In response to such a shock, the global GDP factor declines, with patterns that are broadly similar to those found for the U.S. GDP. As in the case of the effects of global credit shocks, however, the dynamic effects generally are statistically significant for activity but not inflation and nominal interest rates. ${ }^{21}$

\footnotetext{
${ }^{21}$ As in the case of the global VAR, we also identify other structural U.S. specific shocks using the identification schemes described in section II. The impulse responses to these shocks are presented in Figures B4 to B6 in Appendix B. The findings are broadly consistent with the ones from the global VARs.
} 
Table 2 presents our findings with respect to the variance decompositions. U.S. credit shocks play an important role in explaining the variance of domestic macroeconomic aggregates. For example, they account for 13 percent of fluctuations in the U.S. GDP (based on the 12 quarters ahead forecast error variance). Our estimate of the fraction of variance of the U.S. GDP due to a credit shock is consistent with the findings by Meeks (2009). ${ }^{22}$ More interestingly, the U.S. credit shocks account for 13 percent of the variance of global GDP confirming the important role played by the disturbances in the U.S. credit markets for the global economy.

We also compute variance decompositions for other structural U.S. specific shocks along the lines described in section II. Comparing across shocks, the proportion of the 12quarter ahead forecast error variance explained by each shock fluctuates around a uniform 13 percent. This reiterates our earlier point that credit shocks are as important as other macroeconomic shocks in explaining business cycle fluctuations.

How important are U.S. credit shocks during global recessions? To answer this question, we conduct a set of counterfactual exercises as in the previous section. Figure 6a (Figure 6b)shows the differences between the actual cumulative change in the demeaned U.S. GDP (global GDP factor) and the cumulative changes in the simulated values of the same variables in the absence of the U.S. credit shock during the three episodes we identify in the previous section. Figures 7a-7b displays the differences between the actual and counterfactual simulations for all the shocks.

Three major findings stand out from these figures. First, credit shocks again account for the largest difference in the cumulative GDP change during the latest episode in the counterfactual simulations, both for the U.S. GDP and the global GDP factor. This

22 The variance decompositions based on shocks, which are identified with sign restrictions, are generally different from those based on the standard recursive decompositions. We, thus, restrict comparison of our results against those studies utilizing sign restrictions only (see Meeks (2009) for a similar point). 
finding corroborates our earlier results and current views about the main driving force behind the latest episode.

The important role played by credit market disturbances in explaining the severity of recessions during certain episodes is also consistent with some recent studies. For example, Claessens, Kose, and Terrones (2009, 2010) analyze the interactions between recessions and disruptions in credit and asset markets using a sample of 122 recessions in 21 advanced countries. Their findings suggest that when recessions coincide with a substantial decline in credit, they tend to become deeper.

Second, the 1991 downturn in the U.S. was associated with adverse disturbances in the credit markets, but not necessarily elsewhere. This conclusion follows from two facts. On the one hand, U.S. credit shocks account for the largest difference between actual and counterfactual simulations in the case of U.S. GDP, but not in the case of global GDP. On the other hand, our earlier counterfactual simulations with the global VAR have already shown that credit shocks generally do not account for the largest differences between actual and counterfactual global GDP in the 1991 episode. This suggests that not all U.S. credit shocks need to have strong global repercussions. Indeed, the 1991 credit shock in the U.S. is widely seen as having had a strongly local component, as it primarily involved financial institutions that were not internationally integrated. Specifically, the 1991 episode is associated with problems in the savings-and-loan industry in the United States.

Third, the U.S. FAVAR models confirm that the 2001 global downturn was not an adverse credit event. Both the 1991 and 2009 global recessions coincided with financial crises. However, as noted above, the 2001 episode, unlike the 1991 and 2009 global recessions, is associated with disruptions in equity markets while the credit market was only responding to contraction in activity. Indeed, our findings confirm that U.S. based credit market disturbances did not appear to have played a meaningful role in explaining variations in either U.S. GDP or the global GDP factor in this episode. Our results are also consistent with those reported by Claessens, Kose, and Terrones $(2009,2010)$ who 
find that recessions associated with equity price busts are not deeper than other recessions.

\section{Conclusion}

The latest financial crisis has been a bitter reminder of the important role played by credit markets in driving macroeconomic fluctuations. Although there has been a large research program analyzing how gyrations in credit markets translate into fluctuations in the real sector at the country level, the global dimensions of this issue have not yet been studied. Our paper aims to provide a perspective about the linkages between credit markets and global business cycles fluctuations using a simple framework. In particular, we analyze the importance of credit market shocks for the G-7 countries using a global VAR model.

We start with a set of impulse responses to get a grasp of the dynamic reactions to disturbances in credit markets. We find that these disturbances have a significant impact on output, but their effects on other variables are not always substantial. We then conduct variance decompositions to analyze how important the credit market shocks in driving output fluctuations. The results of this exercise suggest that these shocks are as important as other potential shocks, including productivity, demand, and policy shocks.

We then assess the role of credit shocks during global recessions. In particular, we undertake a series of counterfactual exercises to examine the evolution of global GDP during the 1991 and 2009 global recessions. We find that credit shocks have played an important role during the latest global recession. Our simulations indicate that the impact of credit shocks during the 1991 global recession is smaller, but this is mostly due to the U.S. specific nature of the credit shock and the confluence of other factors during this episode.

We also study the global implications of credit shocks that originate in the U.S. by employing a set of FAVAR models. Our results with respect to the impulse responses and variance decompositions of these models are mostly consistent with the ones from the global VAR models. During the latest episode, U.S. credit shocks have been influential in 
driving global growth dynamics. Moreover, they have played a major role in shaping the evolution of U.S. business cycles during the 1991 recession. However, consistent with our earlier findings, the impact of these shocks on global activity was minor during the 1991 episode.

We plan to extend our study in future work by considering the potential importance of cross-country spillovers through various financial market linkages. In addition to credit markets, it would be interesting to analyze how asset (equity and real estate) market linkages can transmit business cycles across countries. In addition, it would be useful to study the importance of credit market shocks originating in advanced countries for emerging market economies. 


\section{References}

Adrian, Tobias, and Hyun Song Shin, 2009, "Prices and Quantities in the Monetary Policy Transmission Mechanism,” International Journal of Central Banking, International Journal of Central Banking, Vol.5(4), pp. 131-142, December.

Aghion, Philippe, Philippe Bacchetta , and Abhijit Banerjee, 2000, "Currency Crises and Monetary Policy in an Economy with Credit Constraints,” Working Papers, No. 00-07, Swiss National Bank, Study Center Gerzensee.

Balke, Nathan S., 2000, “Credit and Economic Activity: Credit Regimes and Nonlinear Propagation of Shocks,” The Review of Economics and Statistics, Vol.82, No.2, pp.344-349.

Bernanke, Ben and Mark Gertler, 1989, “Agency Costs, Net Worth, and Business Fluctuations,” American Economic Review, Vol. 79, pp.14-31.

Bernanke, Ben S., 1993, "How important is the credit channel in the transmission of monetary policy? : A comment," Carnegie-Rochester Conference Series on Public Policy, Elsevier, Vol. 39(1), pp. 47-52, December.

Bernanke, Ben, Jean Boivin, and Piotr S. Eliasz, 2005, "Measuring the Effects of Monetary Policy: A Factor-augmented Vector Autoregressive (FAVAR) Approach,” The Quarterly Journal of Economics, MIT Press, Vol. 120(1), pp. 387-422, January.

Bernanke, Ben, Mark Gertler, and Simon Gilchrist, 1996, “The Financial Accelerator and the Flight to Quality,” The Review of Economics and Statistics, Vol. 78, No. 1, (Feb.), 1-15.

Bernanke, Ben, Mark Gertler, and Simon Gilchrist,1999, "The Financial Accelerator in a Quantitative Business Cycle Framework," in Handbook of Macroeconomics, Vol. 1C, Handbooks in Economics, Vol. 15. Amsterdam: Elsevier, pp. 13411393.

Blanchard, Olivier, and John Simon, 2001, “The Long and Large Decline in U.S. Output Volatility,” Brookings Papers on Economic Activity, Economic Studies Program, The Brookings Institution,Vol. 32(2001-1), pp.135-174.

Bordo, Michael D., and Joseph G. Haubrich, 2010, "Credit crises, money and contractions: An historical view,” Journal of Monetary Economics, Vol.57, pp.118.

Borio, Claudio, Craig Furfine, and Philip Lowe, 2001, "Procyclicality of Financial Systems and Financial Stability,” BIS Papers No.1 (Basel, Switzerland: Bank for International Settlements).

Brunnermeier, Markus K., and Yuliy Sannikov, 2010, “A Macroeconomic Model with Financial Sector,” Working Paper. 
Caballero, Ricardo, and Arvind Krishnamurthy, 1998, "Emerging Market Crises: An Asset Markets Perspective,” Working papers 98-18, Massachusetts Institute of Technology (MIT), Department of Economics.

Campbell, J. Y., 2003, “Consumption-based asset pricing,” Chapter 13 in Constantinides, G. M., Harris, M. and Stulz R. (eds.), Handbook of the Economics of Finance, Amsterdam: Elsevier North-Holland.

Céspedes, Luis Felipe, Roberto Chang, and Andrés Velasco, 2004. "Balance Sheets and Exchange Rate Policy," American Economic Review, American Economic Association, Vol. 94, No.4, pp. 1183-1193, September.

Claessens, Stijn, M. Ayhan Kose, and Marco Terrones, 2009, "What Happens During Recessions, Crunches, and Busts?” Economic Policy, October, pp. 653-700.

Claessens, Stijn, M. Ayhan Kose, and Marco Terrones, 2010, "How do Business and Financial Cycles Interact?” forthcoming IMF Working Paper.

Cochrane, John H., 2006, "Financial Markets and the Real Economy," in John H. Cochrane, ed., Financial Markets and the Real Economy Volume 18 of the International Library of Critical Writings in Financial Economics, London: Edward Elgar, p.xi lxix.

Fisher, Irving, 1933, "The Debt-Deflation Theory of Great Depressions,” Econometrica, Vol. 1 (October), pp. 337-357.

Geanakoplos J., 2009, “The leverage cycle,” NBER Macroecon. Annu. In press.

Gertler, Mark, 1988, "Financial Structure and Aggregate Economic Activity: An Overview,” Journal of Money, Credit and Banking, Blackwell Publishing, Vol. 20, No.3, pp. 559-588, August

Gertler, Mark, and Nohubiro Kiyotaki, 2010 "Financial Intermediation and Credit Policy in Business Cycle Analysis," Working Paper.

Gilchrist, Simon, and Egon Zakrajsek, 2008, "Linkages Between Financial and Real Sectors," unpublished, Academic Consultants Meeting, Federal Reserve Board, Oct.,3.

Gilchrist, Simon, and Egon Zakrajsek, 2010, "Credit Spreads and Business Cycle Flactuations,” unpublished, Boston University, Department of Economics.

Gilchrist, Simon, Vladimir Yankov, and Egon Zakrajsek, 2009, "Credit Market Shocks and Economic Fluctuations: Evidence from Corporate Bond and Stock Markets," NBER Working Papers 14863, National Bureau of Economic Research.

Gorton, Gary, 2009, "Information, Liquidity, and the (Ongoing) Panic of 2007," American Economic Review, Papers and Proceedings, Vol.99(2), pp.567-572.

Imbs, Jean, 2010, “The First Global Recession in Decades,” Paris School of Economics, Working Paper. 
Kannan, Prakash, 2010, "Credit Conditions and Recoveries from Recessions Associated with Financial Crises,” IMF Working Papers 10/83, International Monetary Fund.

Kashyap, Anil K. and Jeremy C. Stein, 2000, "What Do a Million Observations on Banks Say about the Transmission of Monetary Policy?," American Economic Review, 90, June 2000, pp.407-428.

Kiyotaki, Nobuhiro, and John Moore, 1997, “Credit Cycles,” Journal of Political Economy, Vol. 105, No.2, pp.211-248.

Kose, Ayhan, M., Otrok, Christopher, and Whiteman, Charles H., 2008. "Understanding the evolution of world business cycles," Journal of International Economics, Elsevier, Vol. 75(1), pp. 110-130, May.

Kose, M. Ayhan, Christopher Otrok, and Charles H. Whiteman, 2003, "International Business Cycles: World, Region, and Country Specific Factors," American Economic Review, Vol. 93, pp. 1216-39.

Kose, M. Ayhan, Prakash Loungani and Marco E. Terrones, 2010, "Global Recessions and Recoveries," forthcoming IMF Working Paper.

Krugman, Paul, 1999, "Balance sheets, the transfer problem, and financial crises," forthcoming in Robert Flood Festschrift volume.

Lowe, P. and Rohling, T., 1993, `Agency Costs, Balance Sheets and The Business Cycle', Reserve Bank of Australia Research Discussion Paper No. 9311.

McConnell, Margaret M., and Gabriel Perez-Quiros, 2000, "Output Fluctuations in the United States: What Has Changed since the Early 1980's?,” American Economic Review, American Economic Association, Vol. 90(5), pp. 1464-1476, December.

Meeks, Roland, 2009, "Credit Market Shocks: Evidence From Corporate Spreads and Defaults,” Working Paper 0906, Federal Reserve Bank of Dallas.

Mendoza, Enrique and Marco E. Terrones, 2008, "An Anatomy of Credit Booms: Evidence from Macro Aggregates and Micro Data,” NBER Working Paper No. 14049 (Cambridge, MA: National Bureau of Economic Research).

Mendoza, Enrique G., 2010, "Sudden Stops, Financial Crises and Leverage," forthcoming, American Economic Review.

Modigliani, F., and M. Miller, 1958, "The Cost of Capital, Corporation Finance and the Theory of Investment,” American Economic Review, Vol.48 (3), pp.261-297.

Peersman, Gert, and Roland Straub, 2009, "Technology Shocks And Robust Sign Restrictions In A Euro Area Svar,” International Economic Review, Vol. 50(3), pp. 727-750, 08.

Schneider, Martin, and Aaron Tornell, 2004, "Balance Sheet Effects, Bailout Guarantees and Financial Crises,” Review of Economic Studies, Blackwell Publishing, Vol. 71, pp. 883-913, 07. 
Stock, James H. , and Mark W. Watson, 2005, "Understanding Changes In International Business Cycle Dynamics,” Journal of the European Economic Association, MIT Press, Vol. 3(5), pp. 968-1006, 09.

Stock, James H., and Mark W. Watson, 2003, "Forecasting Output and Inflation: The Role of Asset Prices," Journal of Economic Literature, American Economic Association, Vol. 41(3), pp. 788-829, September.

Uhlig, Harald, 2005, "What are the effects of monetary policy on output? Results from an agnostic identification procedure,” Journal of Monetary Economics, Elsevier, Vol. 52(2), pp. 381-419, March.

Wheelock, David C., and Mark E. Wohar, 2009, "Can the term spread predict output growth and recessions? a survey of the literature," Review, Federal Reserve Bank of St. Louis, issue Sep, pp. 419-440. 
Figure 1

Global Factors

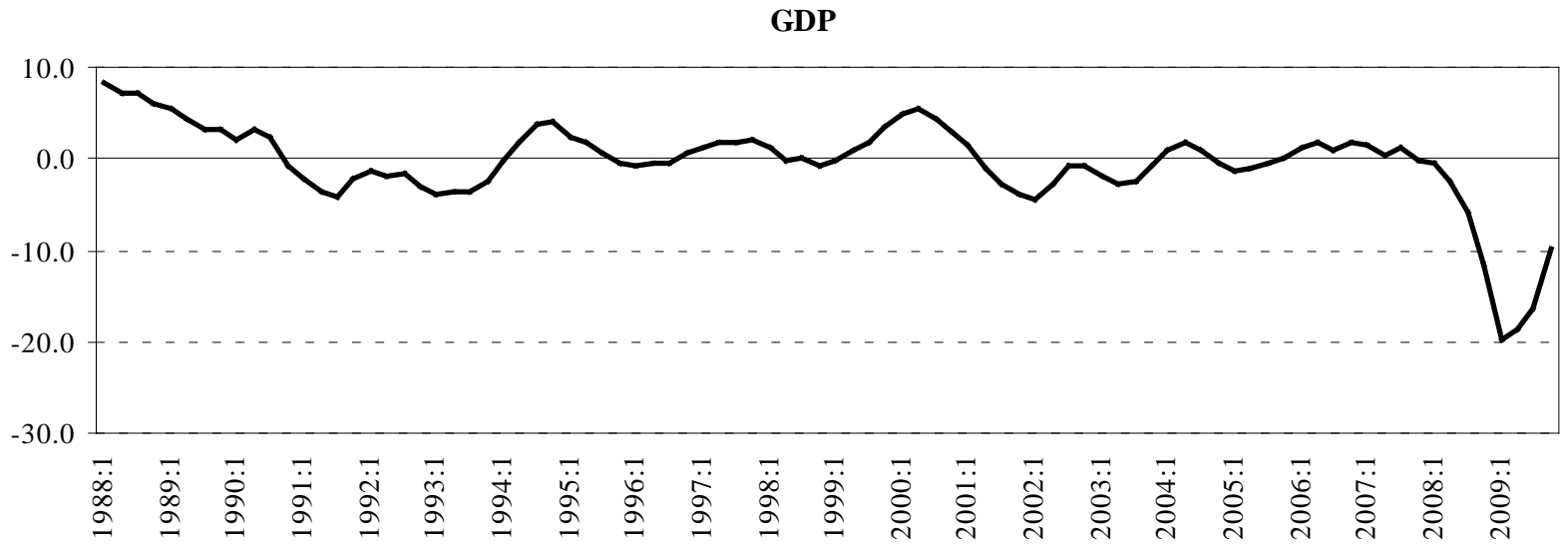

Productivity
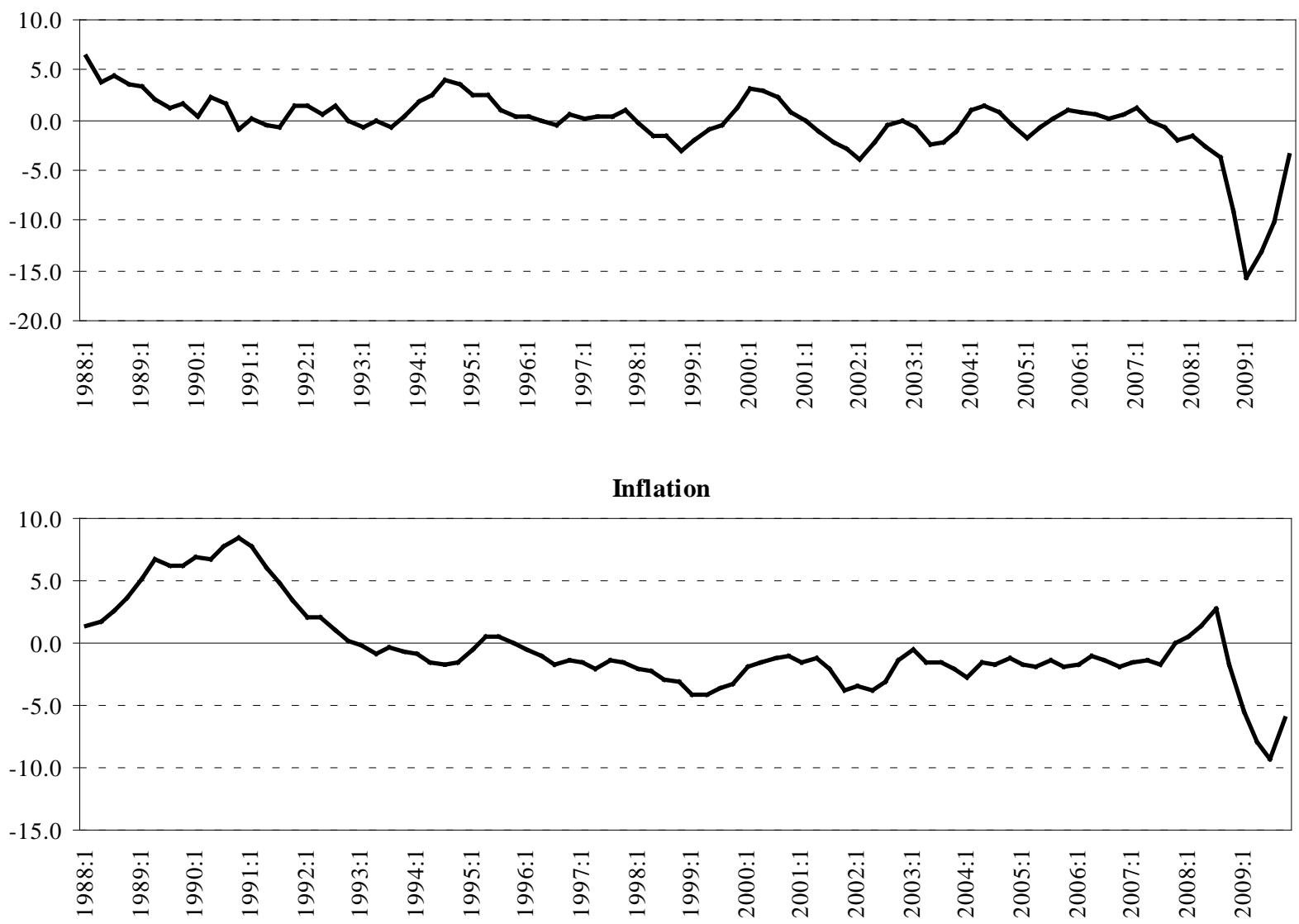


\section{Figure 1 (continued)}

\section{Global Factors}
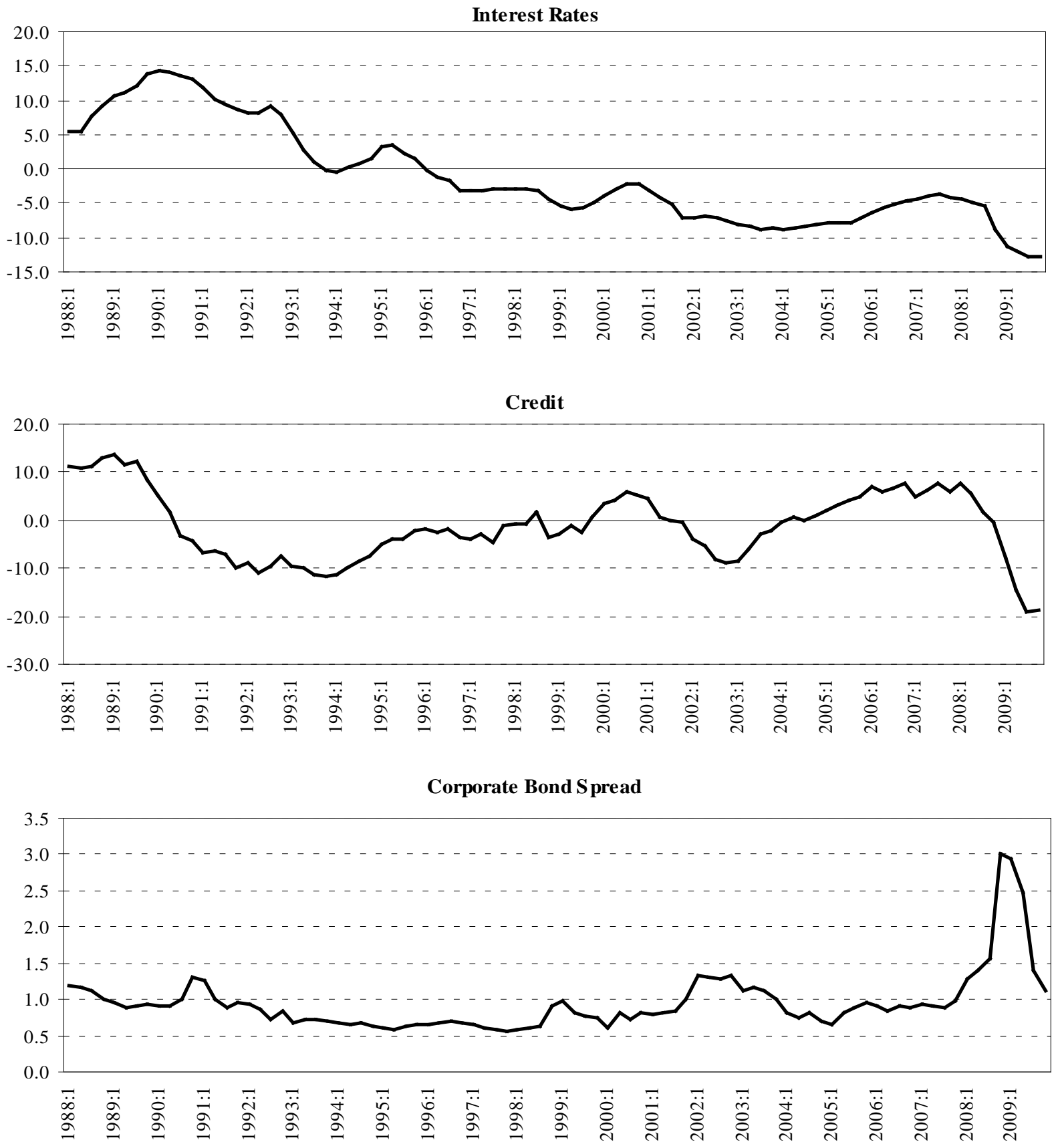

Note: The graphs show the common factors for the G-7 countries estimated using the principal component method. The spread is based on US corporate bond spread only. 
Figure 2

Impulse Responses due to a Credit Shock: Global VAR
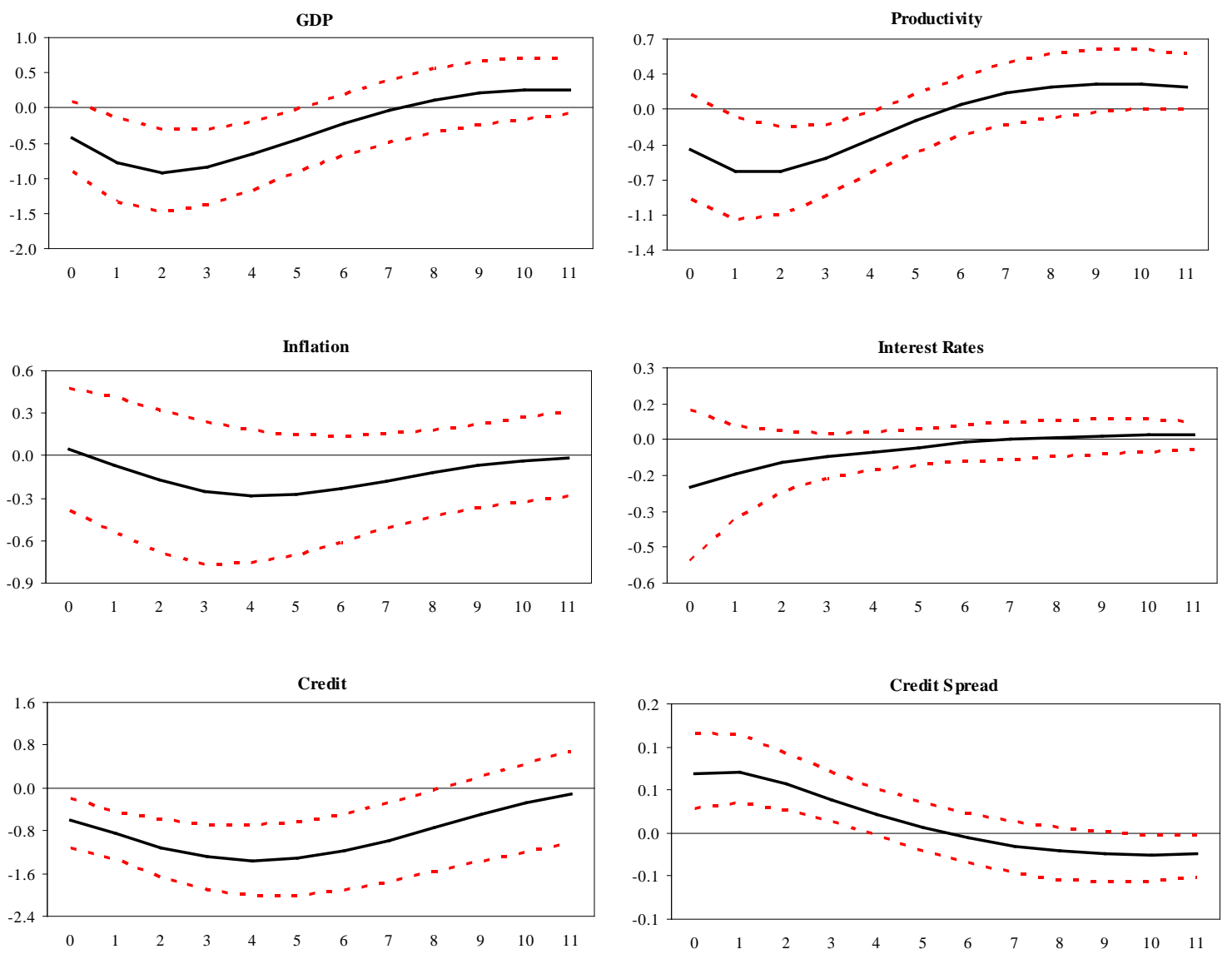

Note: The graphs show the impulse responses of the global factors and the US credit spread due to a 1 standard deviation credit shock in the global VAR model. The solid line represents the median and the dotted lines represent the $16^{\text {th }}$ and the $84^{\text {th }}$ percentiles based on 5000 draws. 
Figure 3

Dynamics of Global GDP: Credit Shock
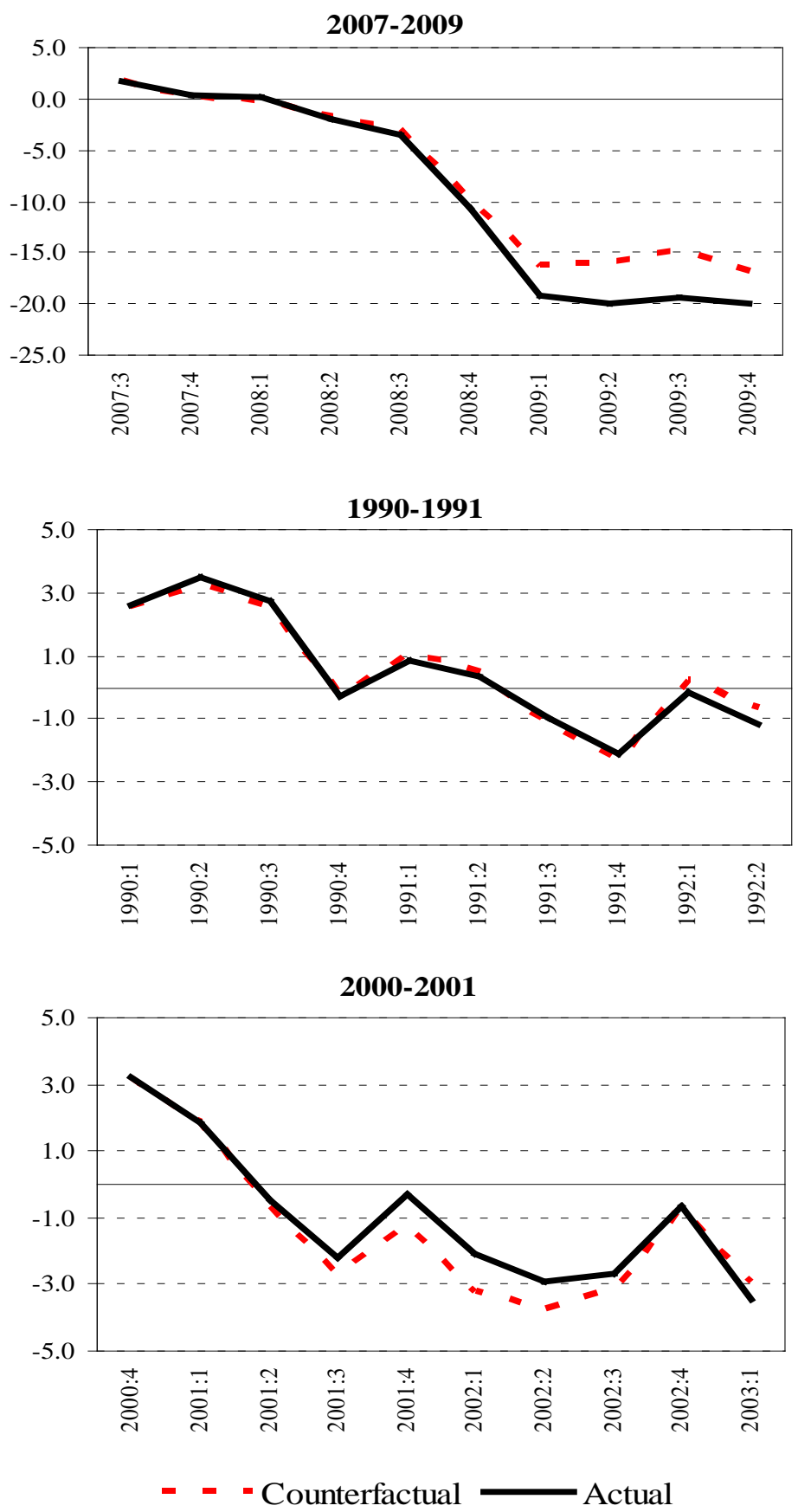

Note: The graphs show the dynamics of cumulative four quarterly growth rates of the global GDP factor during the recessions of 2007-2009, 1990-1991 and 2000-2001 respectively. The solid line represents the actual global GDP factor and the dotted line represents the counterfactual when the global credit shock is set to zero during the period considered. 
Figure 4

Difference between Counterfactual and Actual Global GDP

2007-2009

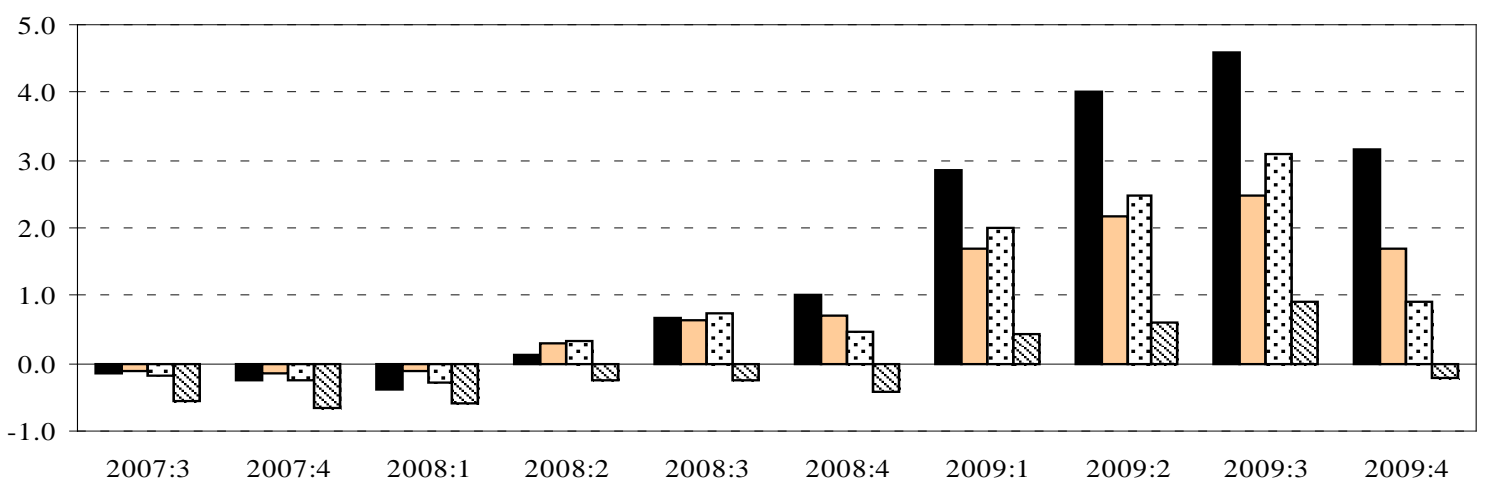

1990-1991

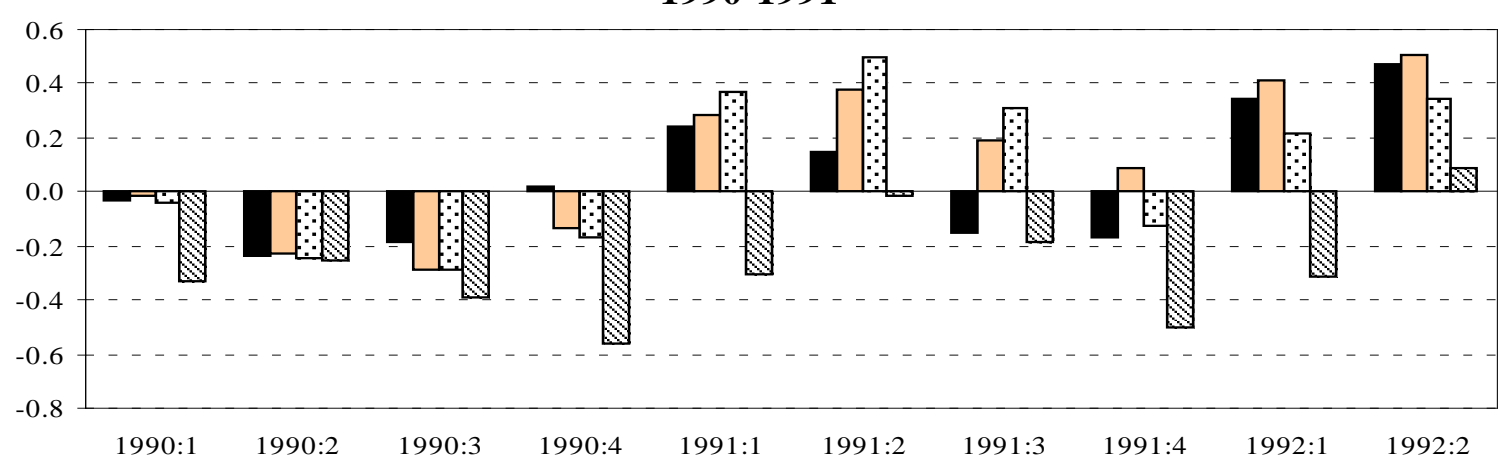

2000-2001

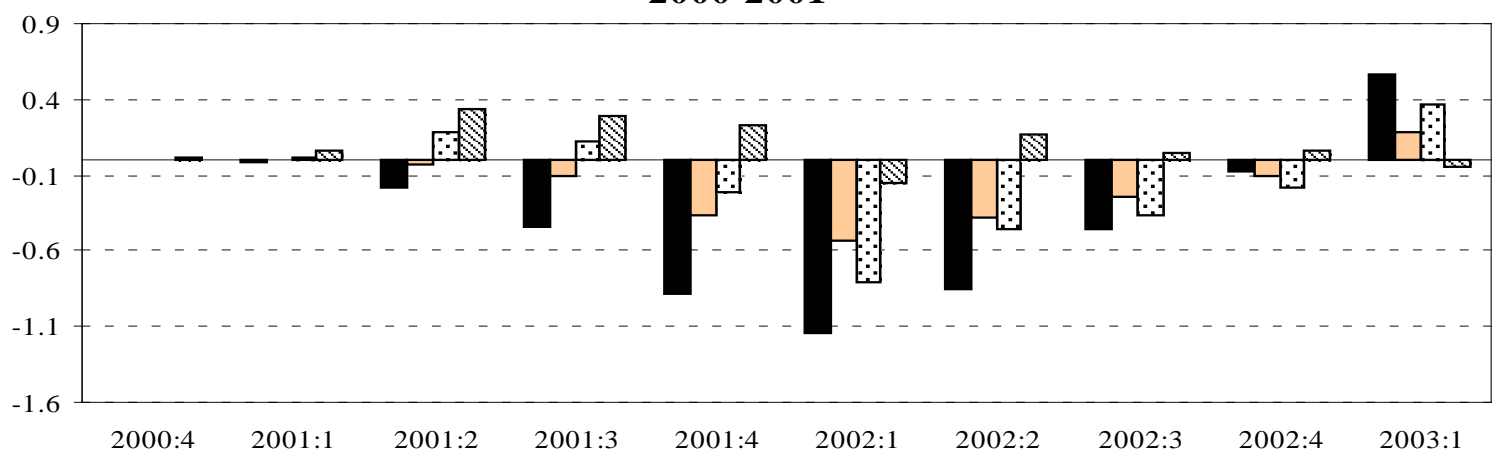

$\square$ Credit $\square$ Productivity $\quad \square$ Policy $\quad$ \& Demand

Note: The graphs show the difference between cumulative four quarterly growth rates of the counterfactual and actual global GDP factor during the recessions of 2007-2009, 1990-1991 and 2000-2001 respectively. The counterfactual is the cumulative growth rates of the global GDP factor when the respective shock is set to zero during the period considered. A positive (negative) bar at each period then captures how the decrease in the global GDP factor would have been lesser (greater) in the absence of the respective shock. 
Figure 5

Impulse Responses due to a Credit Shock: US FAVAR
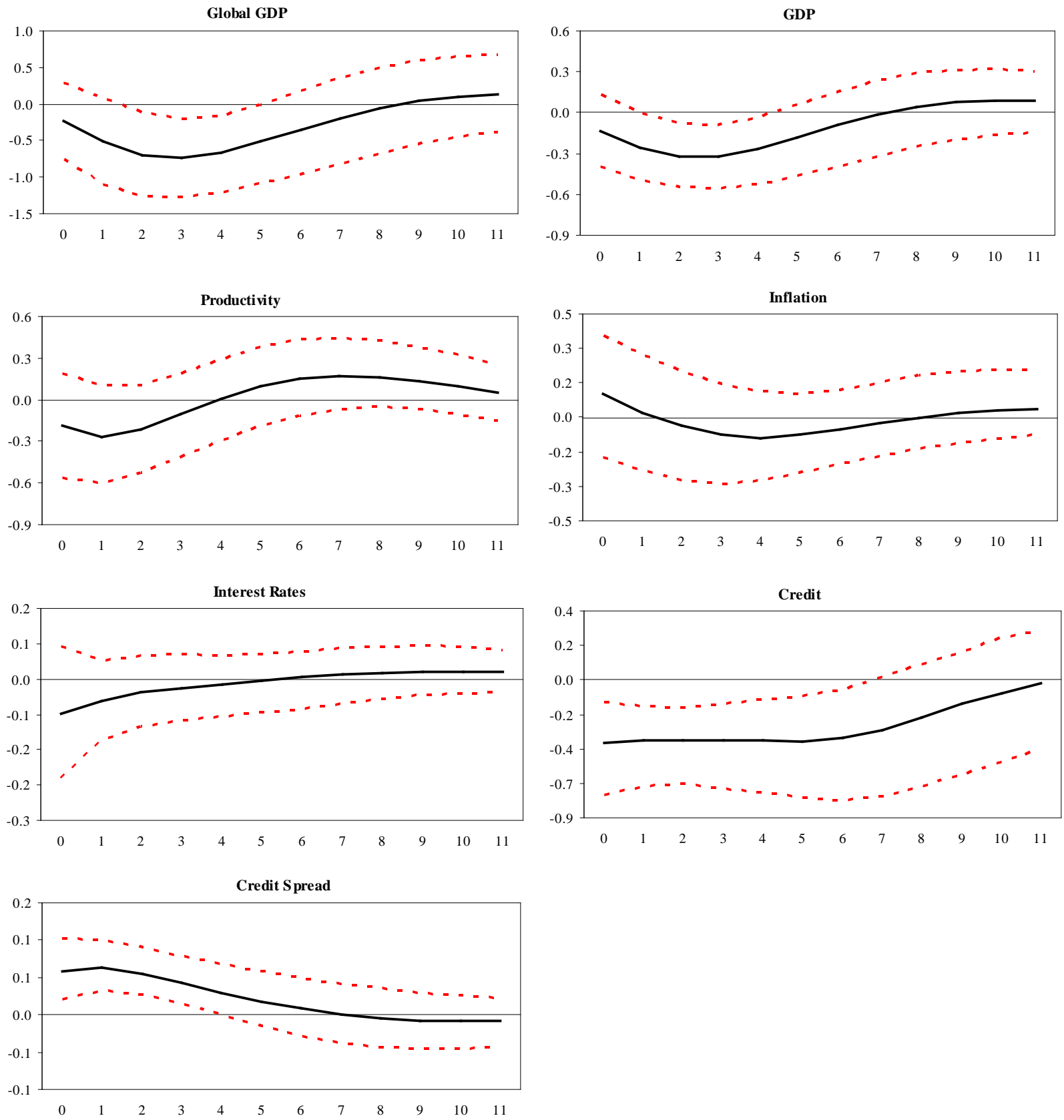

Note: The graphs show the impulse responses of the global GDP factors and the US credit spread due to a 1 standard deviation credit shock in the US FAVAR model. The solid line represents the median and the dotted lines represent the $16^{\text {th }}$ and the $84^{\text {th }}$ percentiles based on 5000 draws. 


\section{Figure 6a}

\section{Dynamics of US GDP: Credit Shock}
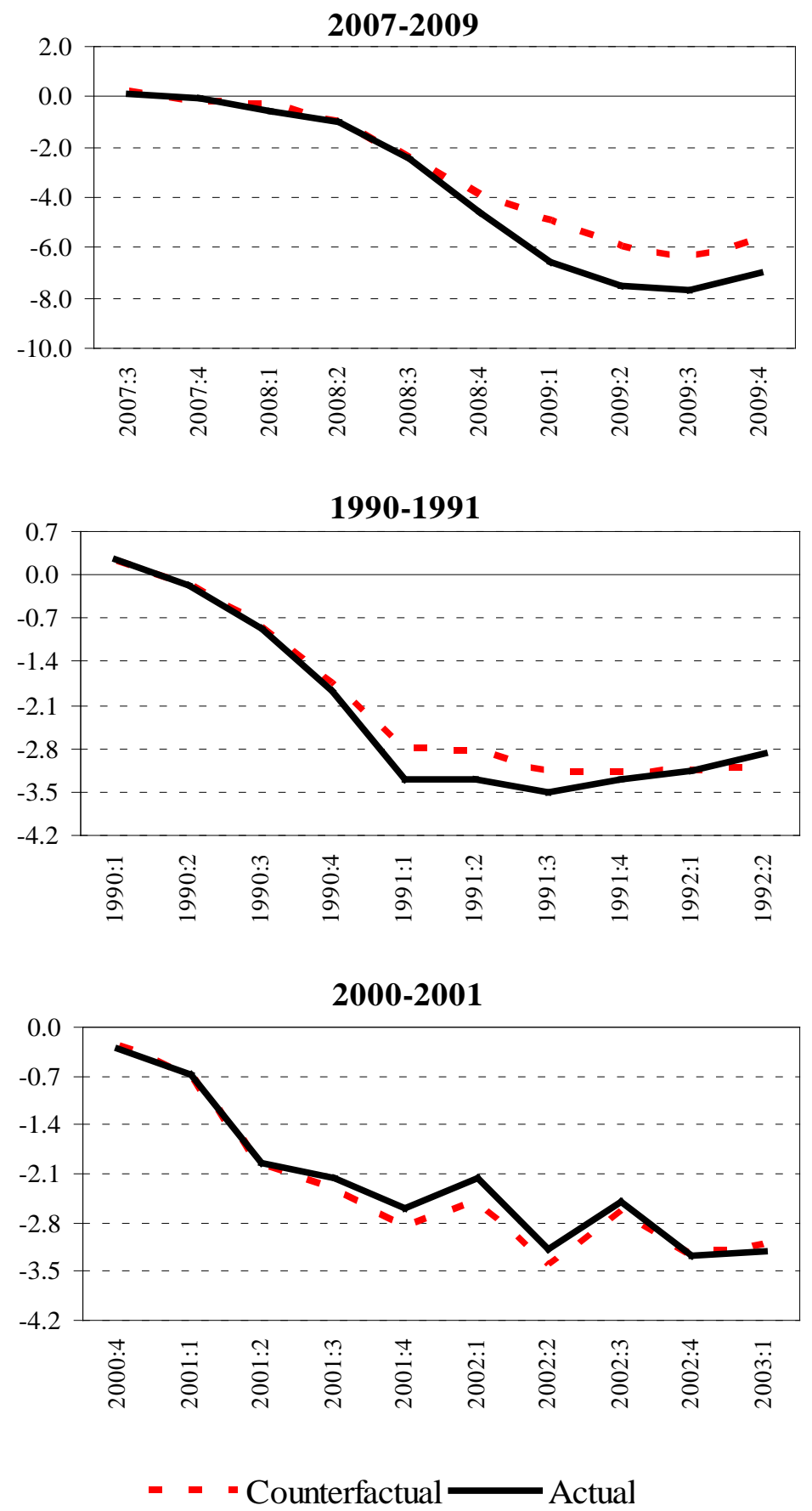

Note: The graphs show the dynamics of cumulative four quarterly growth rates of US GDP during the recessions of 2007-2009, 1990-1991 and 2000-2001 respectively. The solid line represents the actual US GDP and the dotted line represents the counterfactual when the US credit shock is set to zero during the period considered. 


\section{Figure 6b \\ Dynamics of Global GDP: Credit Shock}
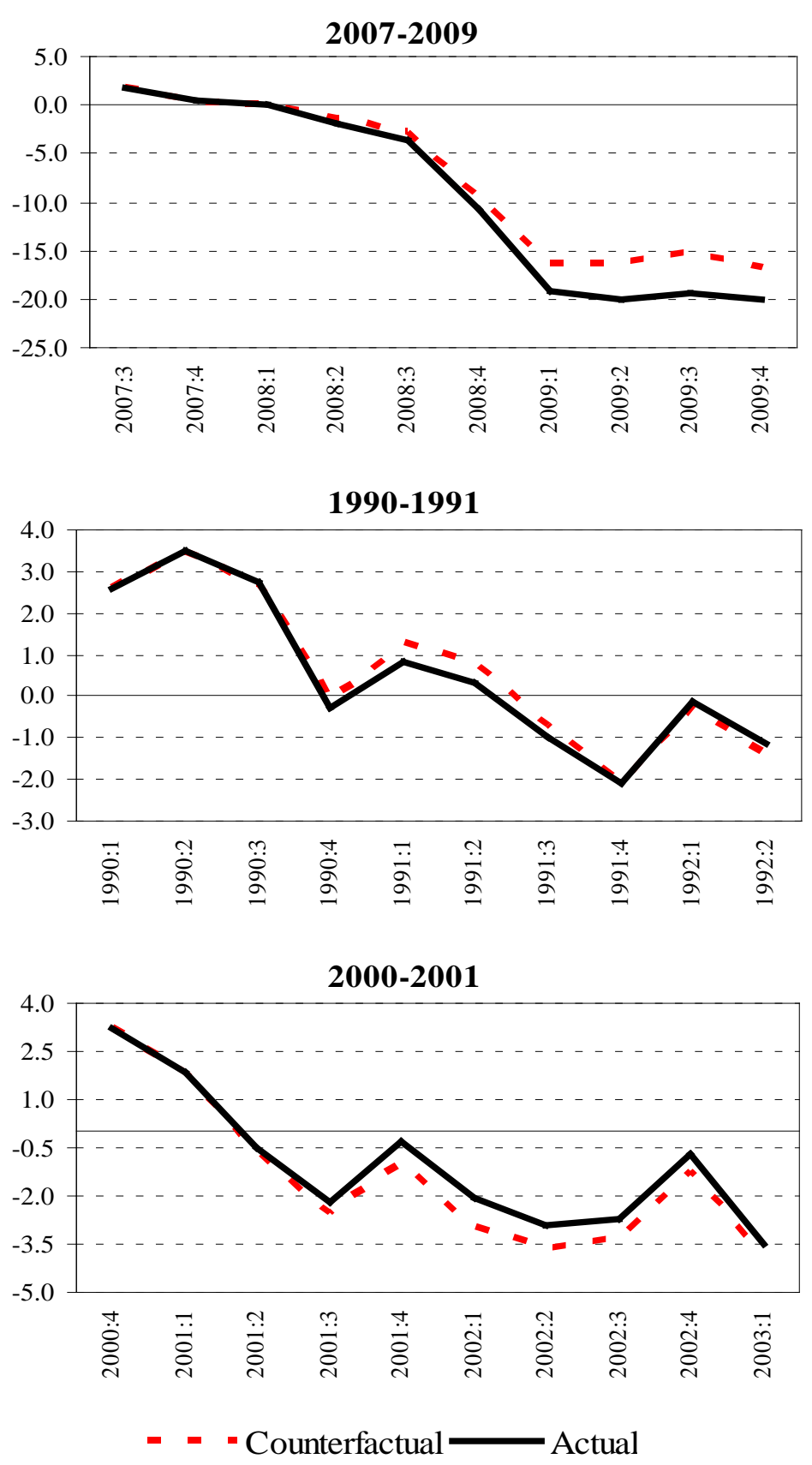

Note: The graphs show the dynamics of cumulative four quarterly growth rates of global GDP factor during the recessions of 2007-2009, 1990-1991 and 2000-2001 respectively. The solid line represents the actual global GDP factor and the dotted line represents the counterfactual when the US credit shock is set to zero during the period considered. 
Figure 7a

Cumulative Growth Gap of US GDP

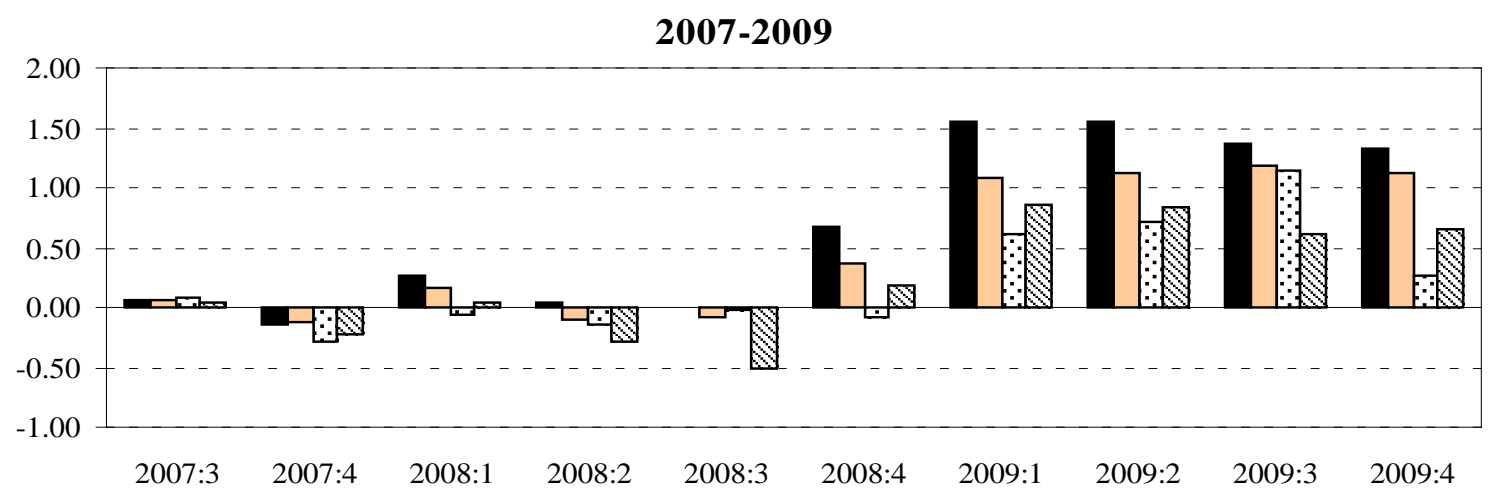

1990-1991
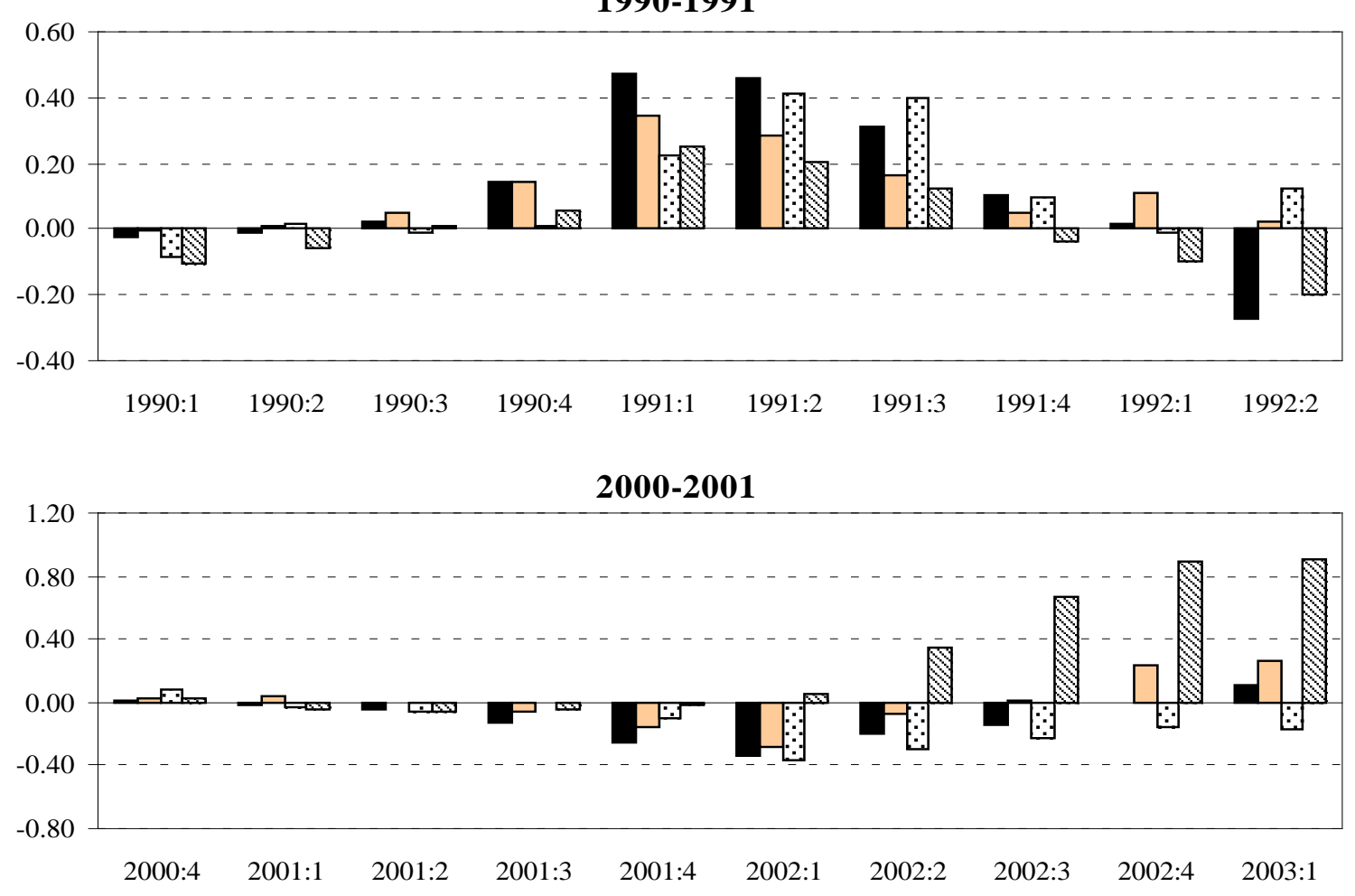

- Credit $\square$ Productivity $\quad$ Policy $\quad$ Demand

Note: The graphs show the difference between cumulative four quarterly growth rates of the counterfactual and US GDP during the recessions of 2007-2009, 1990-1991 and 2000-2001 respectively. The counterfactual is the cumulative growth rates of US GDP when the respective shock is set to zero during the period considered. A positive (negative) bar at each period then captures how the decrease in the US GDP would have been lesser (greater) in the absence of the respective shock. 
Figure 7b

Cumulative Growth Gap of Global GDP
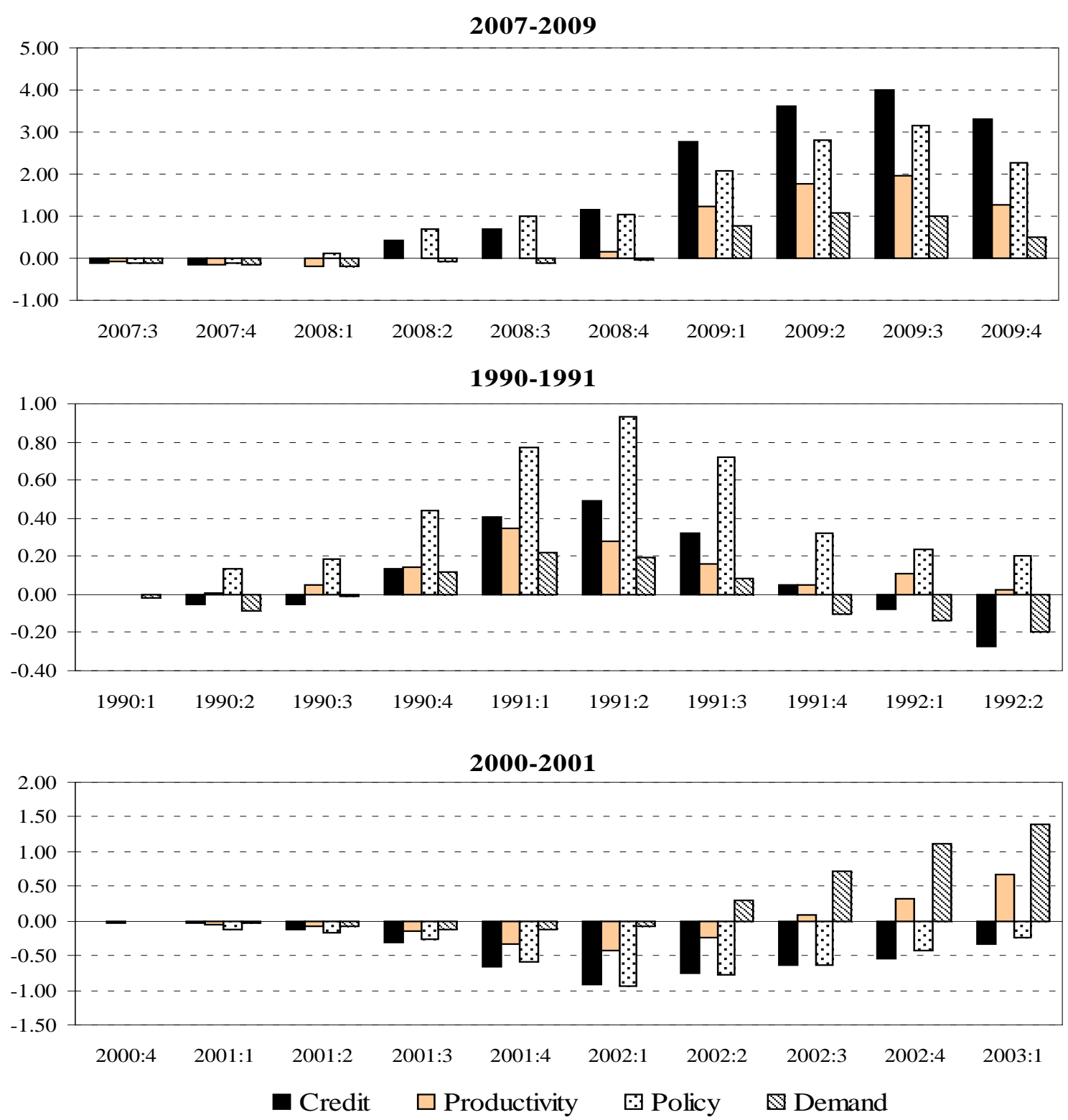

Note: The graphs show the difference between cumulative four quarterly growth rates of the counterfactual and the global GDP factor during the recessions of 2007-2009, 19901991 and 2000-2001 respectively. The counterfactual is the cumulative growth rates of the global GDP factor when the respective shock is set to zero during the period considered. A positive (negative) bar at each period then captures how the decrease in the global GDP factor would have been lesser (greater) in the absence of the respective shock. 
Table 1

Variance Decompositions: Global VAR

Variables

\begin{tabular}{|c|c|c|c|c|c|c|c|}
\hline \multirow[b]{2}{*}{ Shocks } & \multirow[b]{2}{*}{$\begin{array}{l}\text { Forecast horiozon } \\
\text { (in quarters) }\end{array}$} & \multirow[b]{2}{*}{ GDP } & \multirow[b]{2}{*}{ Productivity } & \multicolumn{3}{|c|}{ Variables } & \multirow[b]{2}{*}{ Credit Sread } \\
\hline & & & & Inflation & Interest Rates & Credit & \\
\hline \multirow[t]{4}{*}{ Credit } & 1 & 12.1 & 9.8 & 10.6 & 12.3 & 9.4 & 13.8 \\
\hline & 4 & 12.6 & 11.3 & 13.3 & 13.2 & 14.6 & 14.0 \\
\hline & 8 & 13.6 & 12.3 & 15.5 & 14.3 & 15.7 & 14.6 \\
\hline & 12 & 13.6 & 12.5 & 15.9 & 14.8 & 15.8 & 15.7 \\
\hline \multirow[t]{4}{*}{ Labor Productivity } & 1 & 11.8 & 9.5 & 10.4 & 15.9 & 10.2 & 15.5 \\
\hline & 4 & 12.6 & 10.5 & 12.2 & 15.7 & 13.2 & 15.6 \\
\hline & 8 & 13.4 & 11.2 & 12.9 & 15.6 & 14.7 & 15.4 \\
\hline & 12 & 13.4 & 11.6 & 13.3 & 15.7 & 14.7 & 15.3 \\
\hline \multirow[t]{4}{*}{ Policy } & 1 & 8.4 & 6.1 & 26.6 & 9.7 & 11.8 & 9.9 \\
\hline & 4 & 9.0 & 7.5 & 21.5 & 10.0 & 13.7 & 10.2 \\
\hline & 8 & 10.8 & 8.9 & 17.3 & 11.8 & 15.9 & 12.1 \\
\hline & 12 & 11.9 & 9.8 & 15.9 & 12.5 & 17.3 & 13.1 \\
\hline \multirow[t]{4}{*}{ Demand } & 1 & 9.1 & 1.4 & 13.0 & 8.6 & 9.8 & 6.2 \\
\hline & 4 & 9.2 & 2.8 & 10.4 & 9.2 & 10.7 & 6.7 \\
\hline & 8 & 10.1 & 4.4 & 9.4 & 10.1 & 11.7 & 7.7 \\
\hline & 12 & 10.4 & 5.4 & 9.6 & 10.3 & 12.6 & 8.4 \\
\hline
\end{tabular}

Note: The table shows the proportion of forecast error variance of the global factors and the US credit spread explained by each shock for different forecast horizons, in the global VAR model. Note that in this model, all shocks are global shocks. Figures are the median variance decompositions and are in percentages. As noted in the text, each shock is identified sequentially and hence, the variance decompositions need not add up to 100 . 
Table 2

Variance Decompositions: US FAVAR

\begin{tabular}{|c|c|c|c|c|c|c|c|c|}
\hline \multirow[b]{2}{*}{ Shocks } & \multirow[b]{2}{*}{$\begin{array}{l}\text { Forecast horiozon } \\
\quad \text { (in quarters) }\end{array}$} & \multicolumn{7}{|c|}{ Variables } \\
\hline & & Global GDP & GDP & Productivity & Inflation & Interest Rates & Credit & Credit Spread \\
\hline \multirow[t]{4}{*}{ Credit } & 1 & 10.3 & 8.1 & 8.4 & 8.5 & 10.1 & 9.8 & 10.6 \\
\hline & 4 & 12.4 & 10.5 & 9.8 & 9.9 & 10.4 & 11.9 & 10.7 \\
\hline & 8 & 13.3 & 12.4 & 11.5 & 11.9 & 11.4 & 13.7 & 11.9 \\
\hline & 12 & 13.3 & 12.9 & 12.3 & 12.5 & 12.1 & 14.1 & 12.3 \\
\hline \multirow[t]{4}{*}{ Labor Productivity } & 1 & 11.5 & 16.6 & 6.6 & 7.2 & 11.1 & 8.9 & 12.8 \\
\hline & 4 & 12.8 & 15.9 & 8.7 & 8.9 & 11.4 & 10.2 & 12.7 \\
\hline & 8 & 12.9 & 14.5 & 11.1 & 10.2 & 12.0 & 11.8 & 13.4 \\
\hline & 12 & 13.0 & 14.2 & 11.9 & 10.8 & 12.2 & 12.1 & 13.6 \\
\hline \multirow[t]{4}{*}{ Policy } & 1 & 10.0 & 5.9 & 8.2 & 16.8 & 9.2 & 9.8 & 10.2 \\
\hline & 4 & 11.0 & 9.3 & 11.2 & 16.3 & 10.2 & 11.1 & 10.2 \\
\hline & 8 & 13.3 & 11.8 & 12.8 & 15.4 & 12.1 & 13.2 & 11.8 \\
\hline & 12 & 13.9 & 12.7 & 12.8 & 15.1 & 12.5 & 13.9 & 12.6 \\
\hline \multirow[t]{4}{*}{ Demand } & 1 & 12.7 & 18.4 & 5.2 & 12.0 & 9.4 & 8.4 & 9.8 \\
\hline & 4 & 13.2 & 16.6 & 7.8 & 12.5 & 9.8 & 9.6 & 10.3 \\
\hline & 8 & 13.8 & 15.5 & 10.3 & 13.0 & 10.9 & 11.9 & 11.1 \\
\hline & 12 & 13.7 & 15.4 & 11.2 & 13.6 & 11.4 & 13.0 & 11.2 \\
\hline
\end{tabular}

Note: The table shows the proportion of forecast error variance of the US variables and the global GDP factor explained by each shock for different forecast horizons, in the US FAVAR model. Note that in this model, all shocks are US shocks. Figures are the median variance decompositions and are in percentages. As noted in the text, each shock is identified sequentially and hence, the variance decompositions need not add up to 100 . 


\section{Appendix A}

\begin{tabular}{|c|c|c|c|c|c|}
\hline \multicolumn{6}{|c|}{ Inflation* } \\
\hline Country & Source & Source Base & Database & Code & Description \\
\hline Canada & IFS & EDSS & IFTSTSUB & $15664 \ldots . Z F \ldots$ & CPI:ALL CITIES POP OVR.30,000 \\
\hline France & IFS & EDSS & IFTSTSUB & 13264...ZF ... & CPI: 108 CITIES \\
\hline Germany & IFS & EDSS & IFTSTSUB & $13464 \ldots Z F \ldots$ & CPI Unified Germany \\
\hline Italy & IFS & EDSS & IFTSTSUB & $13664 \ldots \mathrm{ZF} \ldots$ & CPI:ALL ITALY \\
\hline Japan & IFS & EDSS & IFTSTSUB & $15864 \ldots Z F \ldots$ & CPI:ALL JAPAN-485 ITEMS \\
\hline United Kingdom & IFS & EDSS & IFTSTSUB & $11264 \ldots Z F \ldots$ & CPI: ALL ITEMS \\
\hline United States & IFS & EDSS & IFTSTSUB & $11164 \ldots . . Z F \ldots$ & CPI All ITEMS CITY AVERAGE \\
\hline \multicolumn{6}{|c|}{ *Inflation was calculated as the year over year change in CPI } \\
\hline \multicolumn{6}{|c|}{ Nominal Short Term Interest Rate } \\
\hline Country & Source & Source Base & Database & Code & Description \\
\hline Canada & IFS & EDSS & IFTSTSUB & 15660C..ZF... & TREASURY BILL RATE \\
\hline France & IFS & EDSS & IFTSTSUB & 13260C..ZF... & TREASURY BILLS:3 MONTHS \\
\hline Germany & IFS & EDSS & IFTSTSUB & 13460C..ZF... & TREASURY BILL RATE \\
\hline Italy & IFS & EDSS & IFTSTSUB & 13660C..ZF... & TREASURY BILL RATE \\
\hline Japan & IFS & EDSS & IFTSTSUB & 15860C..ZF... & FINANCING BILL RATE \\
\hline United Kingdom & IFS & EDSS & IFTSTSUB & 11260C..ZF... & TREASURY BILL RATE \\
\hline United States & IFS & EDSS & IFTSTSUB & 11160C..ZF... & TREASURY BILL RATE \\
\hline
\end{tabular}


Labour Productivity

\begin{tabular}{|c|c|c|c|c|c|}
\hline Country & Source & Source Base & Database & Code & Description \\
\hline Canada & OECD & EDSS & OETSADB & 156.PDTY & Labour productivity of the total economy \\
\hline France & OECD & EDSS & OETSADB & 132.PDTY & Labour productivity of the total economy \\
\hline Germany & OECD & EDSS & OETSADB & 134.PDTY & Labour productivity of the total economy \\
\hline West Germany & OECD & EDSS & OETSADB & WGR.PDTY & Labour productivity of the total economy \\
\hline Italy & OECD & EDSS & OETSADB & 136.PDTY & Labour productivity of the total economy \\
\hline Japan & OECD & EDSS & OETSADB & 158.PDTY & Labour productivity of the total economy \\
\hline United Kingdom & OECD & EDSS & OETSADB & 112.PDTY & Labour productivity of the total economy \\
\hline United States & OECD & EDSS & OETSADB & 111.PDTY & Labour productivity of the total economy \\
\hline \multicolumn{6}{|c|}{ Gross Domestic Product } \\
\hline Country & Source & Source Base & Database & Code & Description \\
\hline Canada & Statistics Canada & Haver & G10+ & S156NGPC@G10 & Gross Domestic Product (SAAR, Mil.Chn.2002.C\$) \\
\hline France & $\begin{array}{l}\text { Institut National de la Statistique et } \\
\text { des Etudes Economiques }\end{array}$ & Haver & G10+ & S132NGPC@G10 & Gross Domestic Product (SA/WDA, Mil.Chn.2000.Euros) \\
\hline Germany & Deutsche Bundesbank & Haver & G10+ & S134NGPC@G10 & Gross Domestic Product (SA/WDA, Bil.Chn.2000.Euros) \\
\hline Italy & Istituto Nazionale di Statistica & Haver & $\mathrm{G} 10+$ & S136NGPC@G10 & Gross Domestic Product (SA/WDA, Mil.Chn.2000.Euros) \\
\hline Japan & Cabinet Office & Haver & G10+ & S158NGPC@G10 & Gross Domestic Product (SAAR, Bil.Chn.2000.Yen) \\
\hline United Kingdom & Office for National Statistics & Haver & G10+ & S112NGPC@G10 & Gross Domestic Product (SA, Mil.Chained.2005.Pounds) \\
\hline United States & Bureau of Economic Analysis & Haver & G10+ & S111NGPC@G10 & Gross Domestic Product (SAAR, Bil.Chn.2005\$) \\
\hline
\end{tabular}




\begin{tabular}{|c|c|c|c|c|c|}
\hline \multicolumn{6}{|c|}{ Credit } \\
\hline Country & Source & Source Base & Database & Code & Description \\
\hline Canada & IFS & EDSS & IFTSTSUB & 15622D..ZF... & CLAIMS ON PRIVATE SECTOR \\
\hline France & IFS & EDSS & IFTSTSUB & 13222D..ZF... & CREDIT TO PRIVATE SECTOR \\
\hline Germany & IFS & EDSS & IFTSTSUB & 13422D..ZF... & CLAIMS ON OTH RESSID SECTOR \\
\hline Italy & IFS & EDSS & IFTSTSUB & 13622D..ZF... & CLAIMS ON OTHER RESIDENT SECTORS \\
\hline Japan & IFS & EDSS & IFTSTSUB & 15822D..ZF... & CLAIMS ON PRIVATE SECTOR \\
\hline United Kingdom & IFS & EDSS & IFTSTSUB & 11222D..ZF... & CLAIMS ON PRIVATE SECTOR \\
\hline United States & IFS & EDSS & IFTSTSUB & 11122D..ZF... & CLAIMS ON PRIVATE SECTOR \\
\hline \multicolumn{6}{|c|}{ Spread } \\
\hline Country & Source & \multicolumn{2}{|c|}{ Source Base } & Code & Description \\
\hline Spread & Calculated & & & & (Baa Interest Rate- Aaa Interest Rate) \\
\hline Baa & Moody's Investor Services. & \multirow{2}{*}{\multicolumn{2}{|c|}{$\begin{array}{l}\text { Board of Governors of the } \\
\text { Board of Governors of the }\end{array}$}} & & Moody's Seasoned Baa Corporate Bond Yield \\
\hline Aаa & Moody's Investor Services. & & & & Moody's Seasoned Aaa Corporate Bond Yield \\
\hline
\end{tabular}

Note: To complete the data for some series we also use other databases. Details of this are available form the authors on request. 


\section{Appendix B}

Figure B1

Impulse Responses due to a Productivity Shock: Global VAR
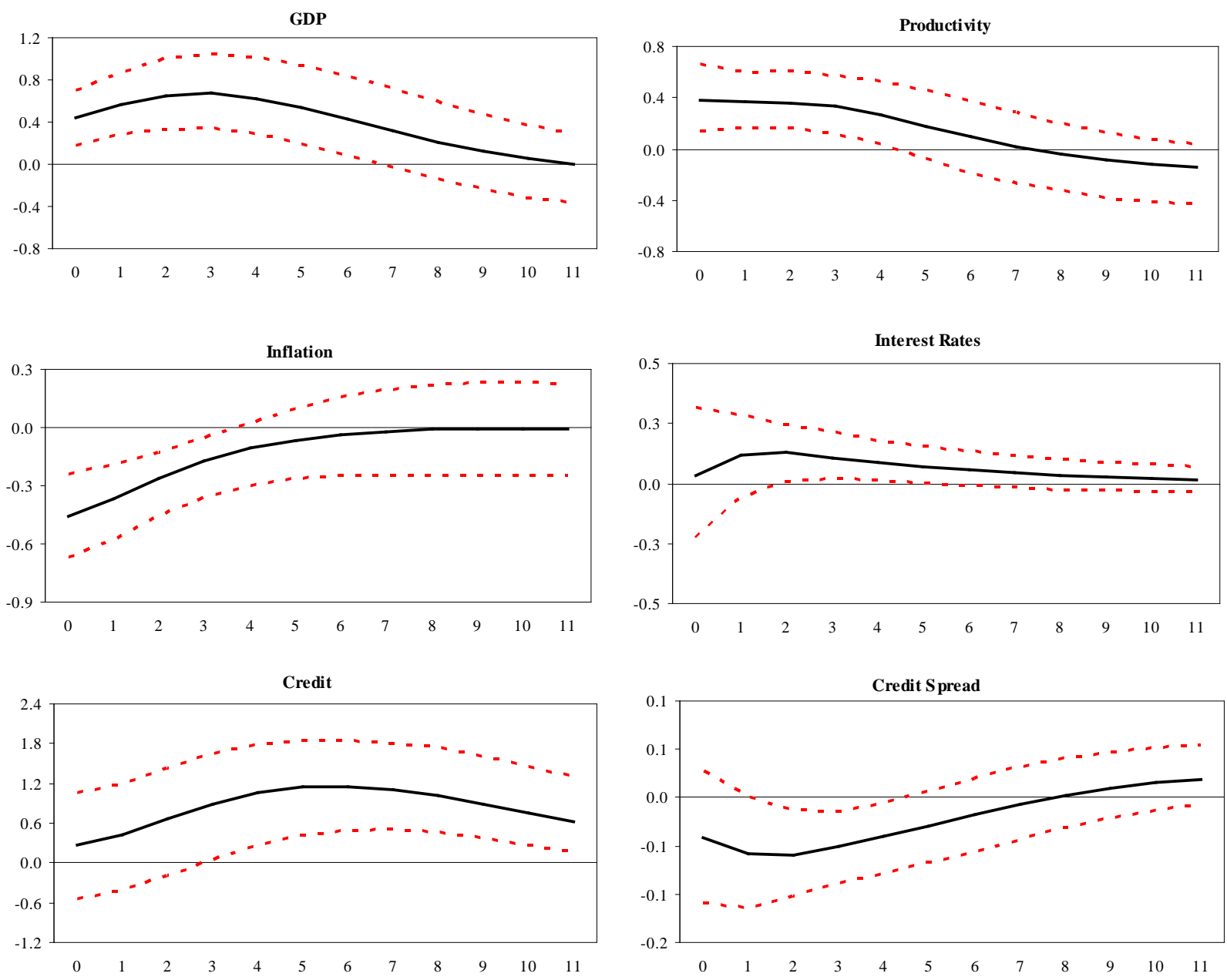

Note: The graphs show the impulse responses of the global factors and the US credit spread due to a 1 standard deviation productivity shock in the global VAR model. The solid line represents the median and the dotted lines represent the $16^{\text {th }}$ and the $84^{\text {th }}$ percentiles based on 5000 draws. 
Figure B2

\section{Impulse Responses due to a Policy Shock: Global VAR}
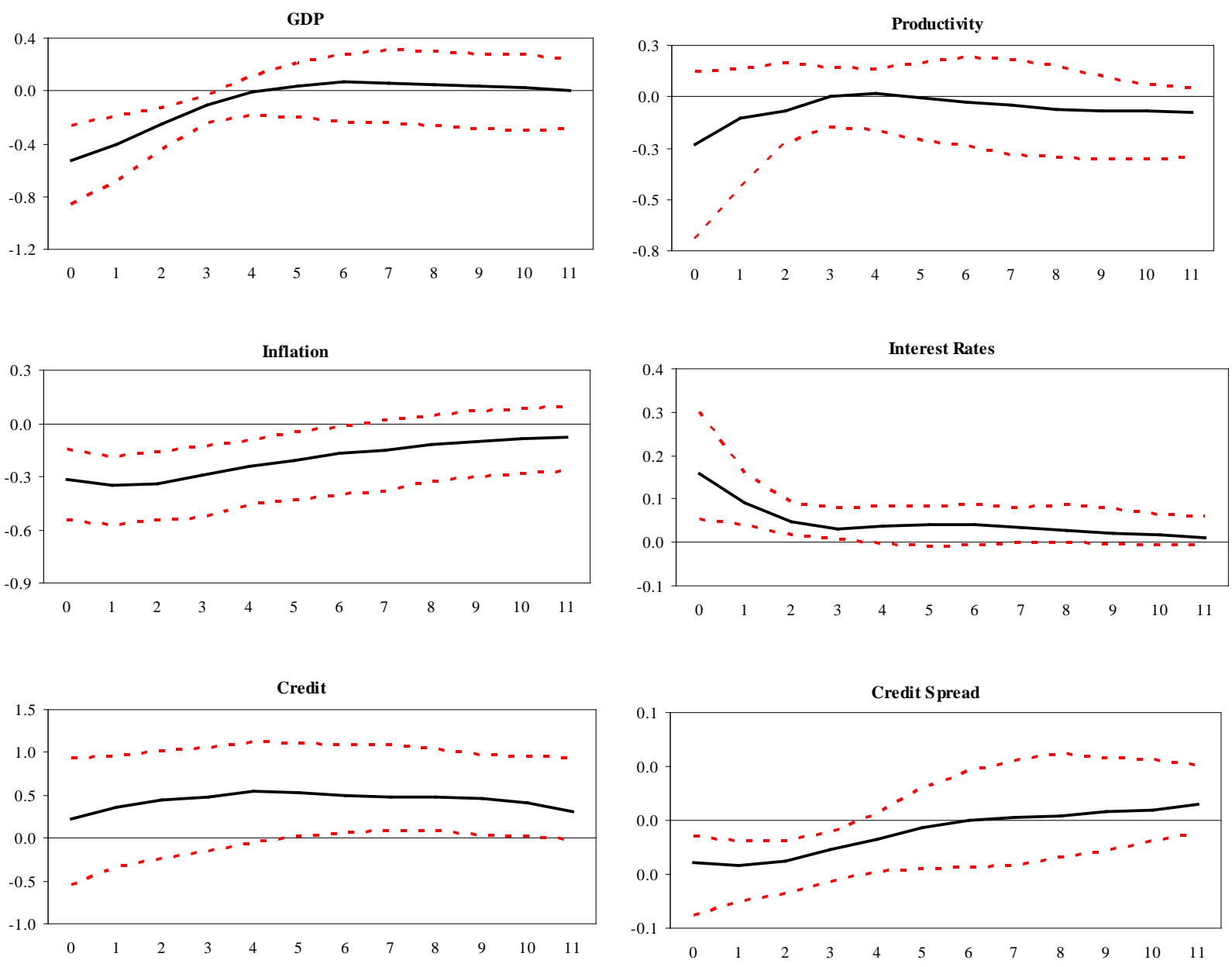

Note: The graphs show the impulse responses of the global factors and the US credit spread due to a 1 standard deviation policy shock in the global VAR model. The solid line represents the median and the dotted lines represent the $16^{\text {th }}$ and the $84^{\text {th }}$ percentiles based on 5000 draws. 
Figure B3

\section{Impulse Responses due to a Demand Shock: Global VAR}
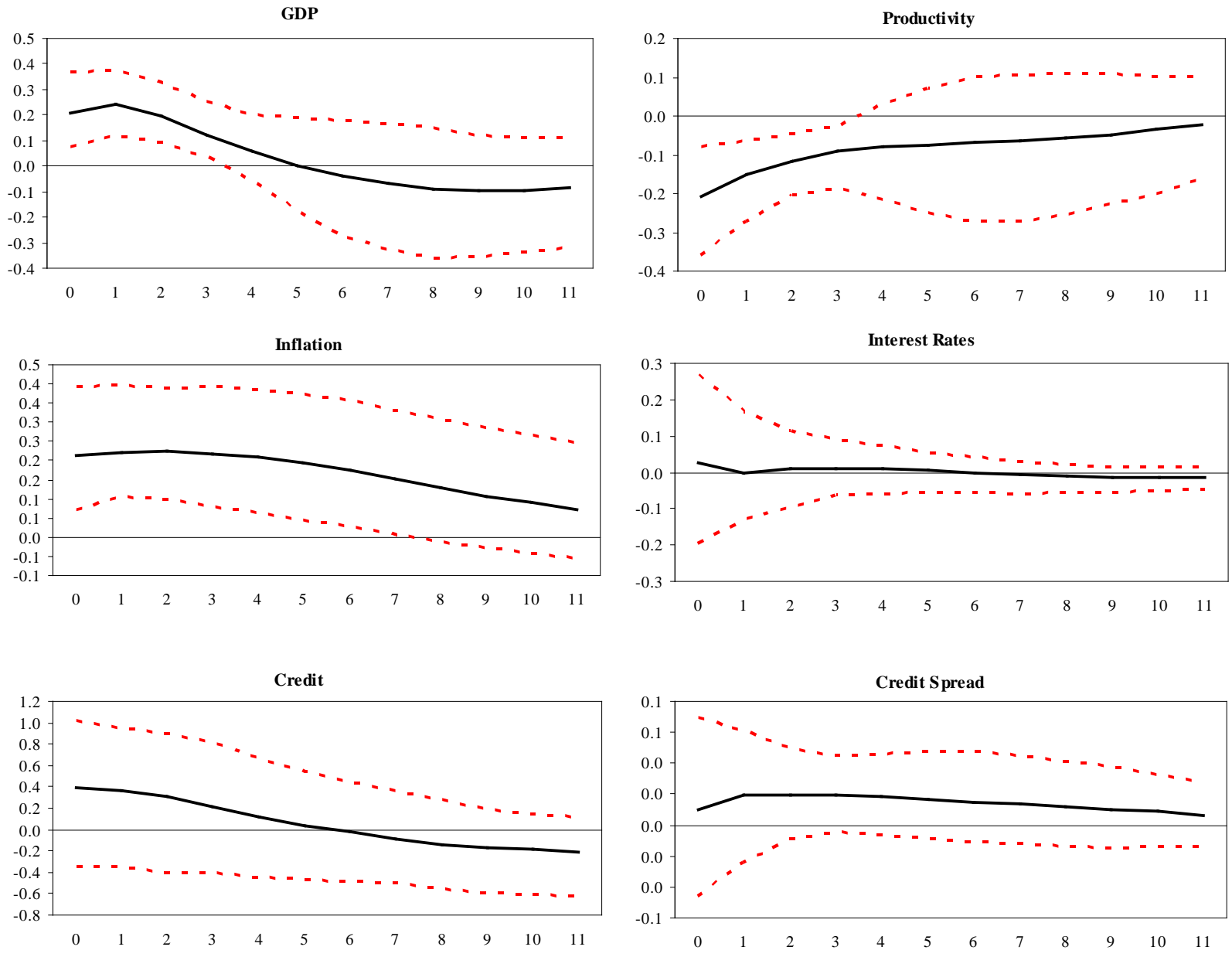

Note: The graphs show the impulse responses of the global factors and the US credit spread due to a 1 standard deviation demand shock in the global VAR model. The solid line represents the median and the dotted lines represent the $16^{\text {th }}$ and the $84^{\text {th }}$ percentiles based on 5000 draws. 
Figure B4

Impulse Responses due to a Productivity Shock: US VAR
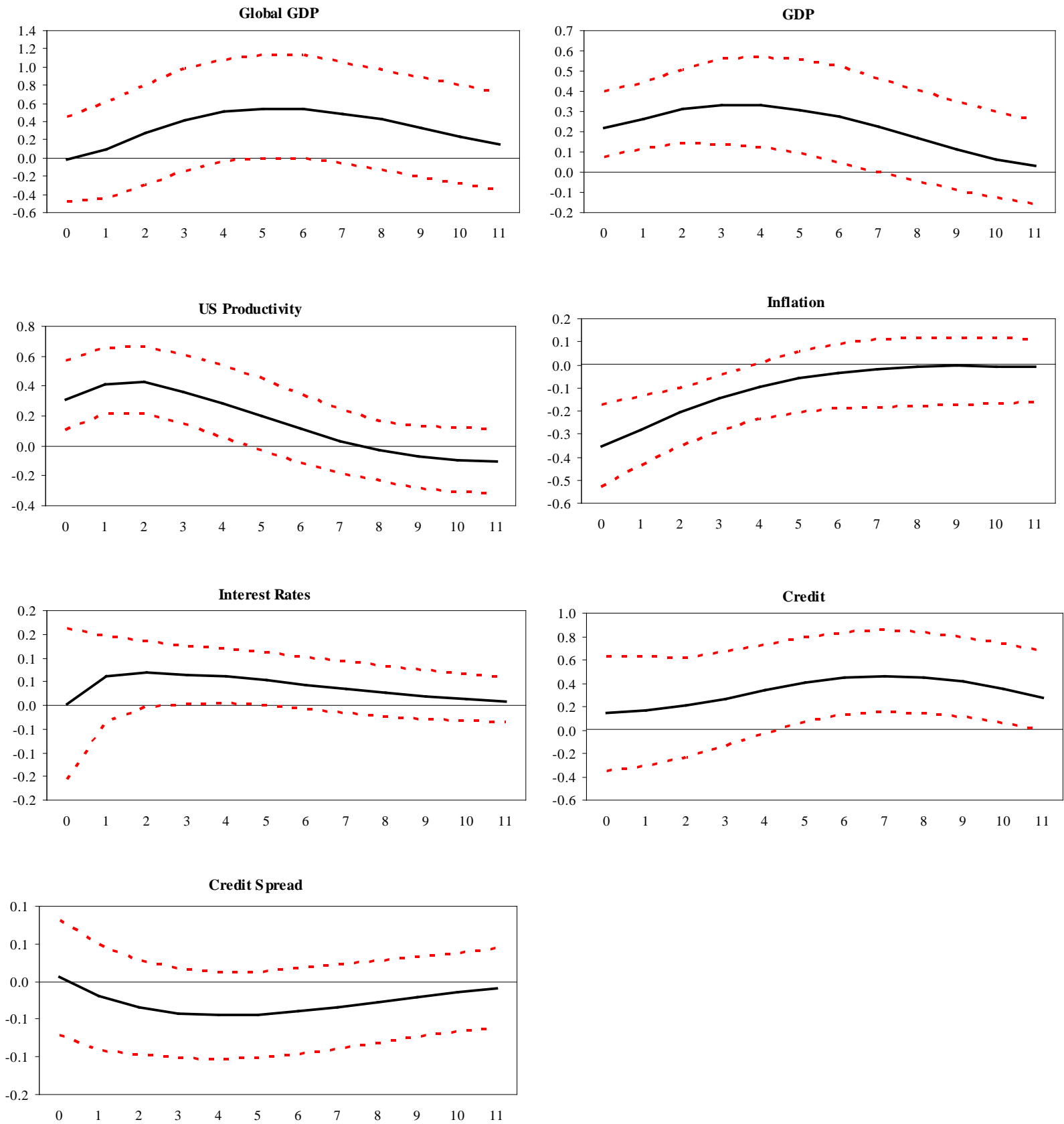

Note: The graphs show the impulse responses of the US variables factors and the global GDP factor due to a 1 standard deviation productivity shock in the US FAVAR model. The solid line represents the median and the dotted lines represent the $16^{\text {th }}$ and the $84^{\text {th }}$ percentiles based on 5000 draws. 
Figure B5

\section{Impulse Responses due to a Policy Shock: US VAR}
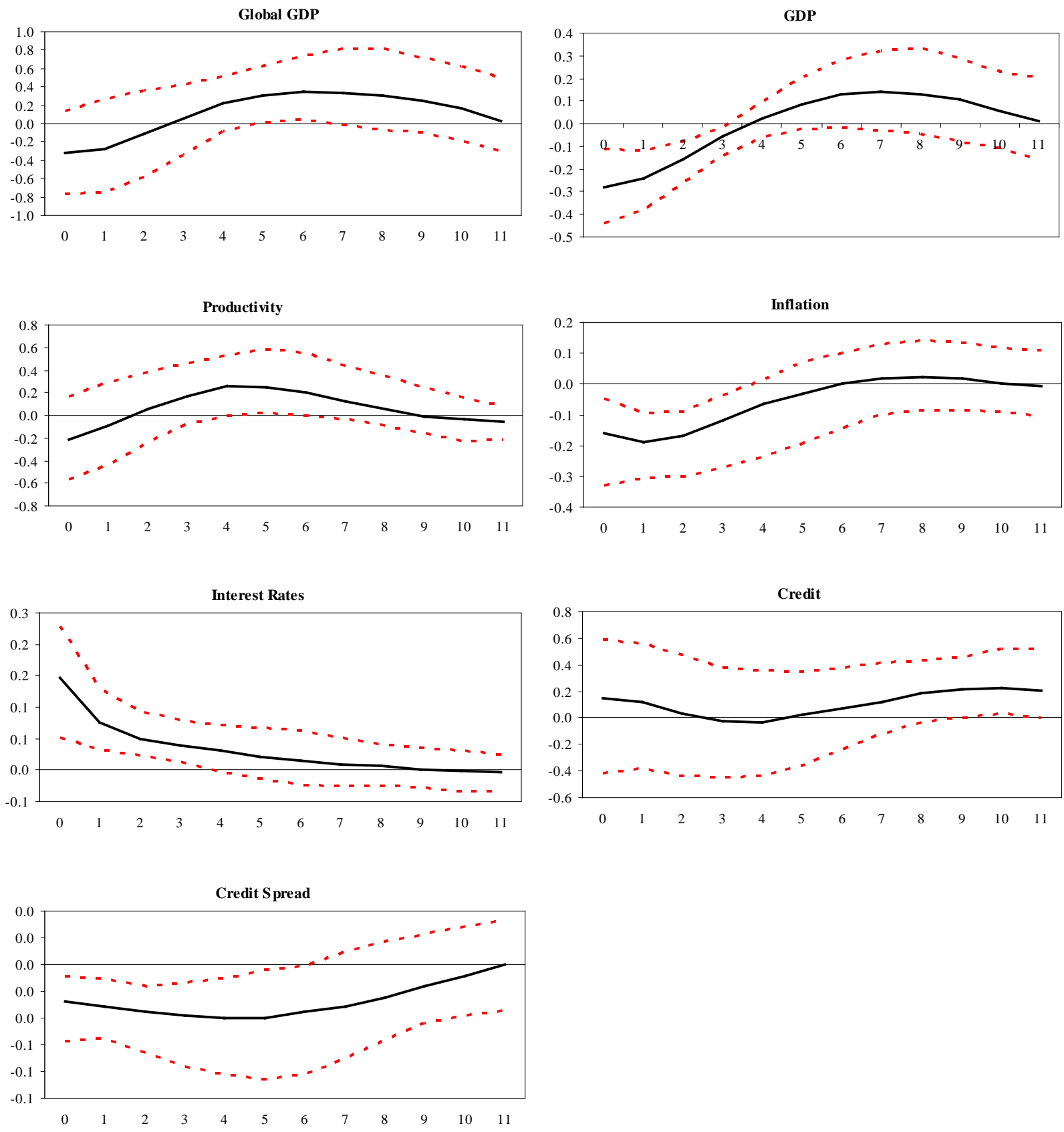

Note: The graphs show the impulse responses of the US variables factors and the global GDP factor due to a 1 standard deviation policy shock in the US FAVAR model. The solid line represents the median and the dotted lines represent the $16^{\text {th }}$ and the $84^{\text {th }}$ percentiles based on 5000 draws. 
Figure B6

\section{Impulse Responses due to a Demand Shock: US VAR}
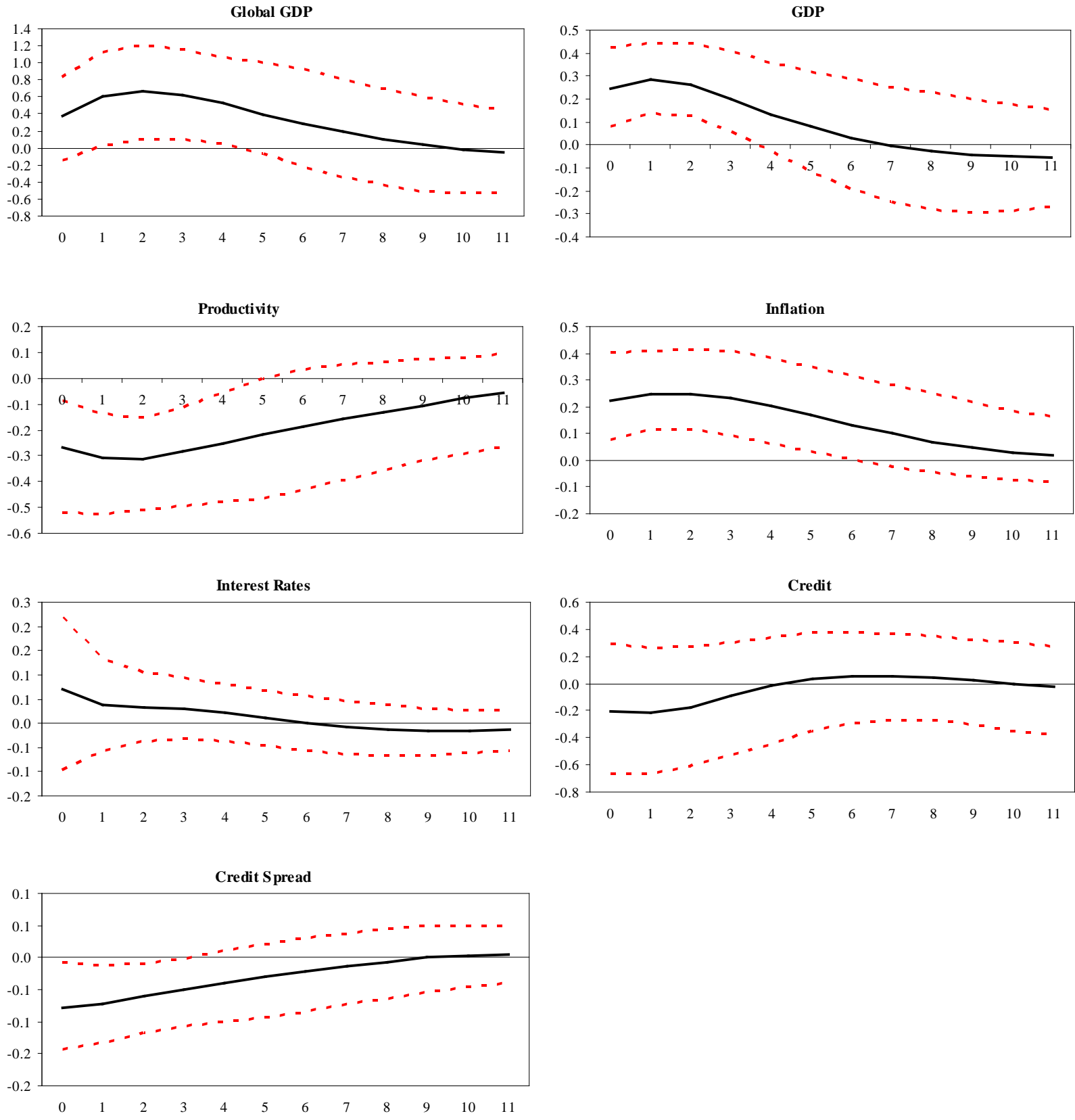

Note: The graphs show the impulse responses of the US variables factors and the global GDP factor due to a 1 standard deviation policy shock in the US FAVAR model. The solid line represents the median and the dotted lines represent the $16^{\text {th }}$ and the $84^{\text {th }}$ percentiles based on 5000 draws. 